\title{
EFEITOS DE REGULADORES VEGETAIS APLICADOS NA \\ CULTURA DA BATATA (Solanum tuberosum L.), APÓS A TUBERIZAÇÃO: ASPECTOS FISIOLÓGICOS E DE PRODUÇÃO
}

\section{SILVIO TAVARES}

Engenheiro Agrônomo

Orientador: Prof. Dr. Antonio Augusto Lucchesi

Dissertação apresentada à Escola Superior de Agricultura "Luiz de Queiroz", Universidade de São Paulo, para obtenção do título de Mestre em Ciências, Área de Concentração: Fisiologia e Bioquímica de Plantas.

PIRACICABA

Estado de São Paulo - Brasil

Julho - 1999 


\title{
Dados Internacionais de Catalogação na Publicação (CIP) DIVISĀO DE BIBLIOTECA E DOCUMENTAÇĀO - Campus “Luiz de Queiroz"/USP
}

\author{
Tavares, Silvio \\ Efeitos de reguladores vegetais aplicados na cultura da batata (Solanum tuberosum L.), \\ após a tuberização: aspectos fisiológicos e de produção / Silvio Tavares. - - Piracicaba, \\ 1999. \\ $62 \mathrm{p}$. \\ Dissertação (mestrado) - - Escola Superior de Agricultura Luiz de Queiroz, 1999. \\ Bibliografia. \\ 1. Batata 2. Fisiologia vegetal 3. Produtividade agricola 4. Regulador de crescimento \\ vegetal 5 . Tuberização I. Título
}

CDD 633.491

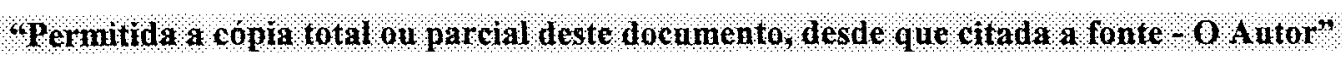




\begin{tabular}{|c|c|c|c|c|}
\hline$p$. & linha & & onde se lê & leia-se \\
\hline iv & quinta & & LITERARURA & LITERATURA \\
\hline viii & oitava & & physiologic aspects & physiological aspects \\
\hline 11 & décima quarta & & $\begin{array}{l}\text {... matéria seca de cada } \\
\text { parcela }\end{array}$ & ... matéria seca total de cada parcela \\
\hline 18 & quarta & & tbérculos & tubérculos \\
\hline 19 & legenda & & CONTROL & CONTROLE \\
\hline 20 & legenda & & CONTROL & CONTROLE \\
\hline 23 & nona & & ... carboidratos de reserva. & ... material orgânico. \\
\hline 24 & $\begin{array}{l}\text { quinta, sexta } \\
\text { sétima }\end{array}$ & $\mathrm{e}$ & $\begin{array}{l}\text { a) ... não afetaram a área } \\
\text { foliar e a massa de matéria } \\
\text { seca das folhas, mas ... }\end{array}$ & $\begin{array}{l}\text {... não afetaram a área foliar e a massa } \\
\text { de matéria secas das folhas. }\end{array}$ \\
\hline 31 & sexta & & Produção & Produtividade \\
\hline 35 & segunda & & $\begin{array}{l}\text {... concentrações podem } \\
\text { aumentaram a produção ... }\end{array}$ & $\begin{array}{l}\text {... concentrações aumentaram a } \\
\text { produção... }\end{array}$ \\
\hline
\end{tabular}

43 décima primeira

... quanto à partição dos ... quanto à partição dos fotoassimilados. fotoassimilados, detectados através da análise de carboidratos.

43 décima segunda e b) A análise de carboidratos eliminar o período décima terceira solúveis totais ...

47 vigésima quinta _.. massa de matéria seca $(\mathrm{g})$ _... massa de matéria seca foliar $(\mathrm{g})$

48 décima segunda $\ldots$ adaptado por ... $\quad .$. adaptado para ...

52 oitava $\quad .$. teor de açúcares em folhas ... teor de sólidos solúveis totais ( ${ }^{\circ}$ Brix) em folhas ...

58 quinta e sexta HOPKINS, W.G. The role of DAVIES, P.J. The role of hormones ... hormones ... In: Introduction In: HOPKINS, W.G. Introduction to to plant physiology, ... plant physiology, ... 
À minha esposa Elisabete, pelo amor, paciência e dedicação

Aos meus filhos: Pedro e Thiago, pela compreensão e carinho

\section{OFEREÇO}

A todos aqueles que desejam um mundo melhor

DEDICO 


\section{AGRADECIMENTOS}

Desejo agradecer a todos aqueles que contribuíram para a realização deste trabalho:

- Professor Dr. Antonio Augusto Lucchesi, pela orientação, incentivo e confiança.

- Ao Sr. Wilson José Ravagnani e a todos do Sítio Roseira, em Sumaré, pela cessão da área e ajuda para a execução dos trabalhos.

- Aos técnicos do Laboratório de Fisiologia vegetal, Bioquímica e Tecnologia de alimentos, pela ajuda e amizade.

- Aos professores Paulo Roberto de Camargo e Castro, Ricardo Ferraz de Oliveira e demais professores pelo exemplo e ensinamentos recebidos.

- À Sra. Maria Cristina Clemente Furlan, pelo incentivo, ajuda e amizade.

- À Bibliotecária Eliana M. G. Sabino e funcionários da Biblioteca Central da ESALQ, pela ajuda e amizade.

- Aos amigos e colegas de estudo do Curso de Fisiologia e Bioquímica de Plantas, pelo companheirismo.

- À Gloriosa ESALQ pela nobre missão.

- À CAPES pela bolsa de estudos concedida.

- À DEUS por mais uma vitória. 


\section{SUMÁRIO}

RESUMO

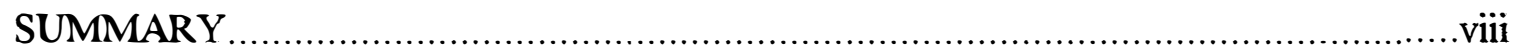

1 INTRODUÇÃO

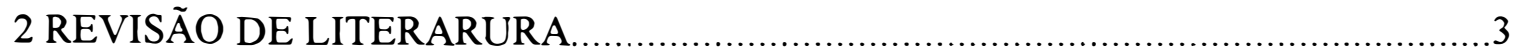

3 ANÁLISE QUANTITATIVA DE CRESCIMENTO NA CULTURA DA BATATA (Solamum tuberosum L.) SOB INFLUÊNCIA DE REGULADORES VEGETAIS, APÓS

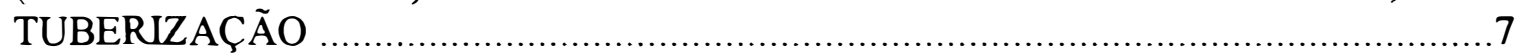

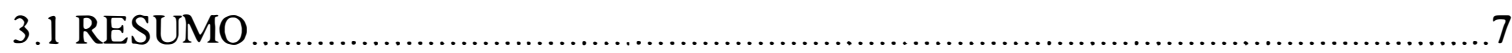

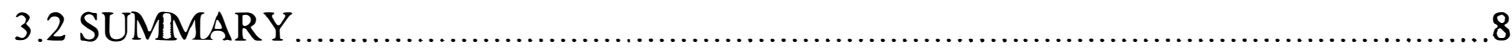

3.3 INTRODUÇÃO

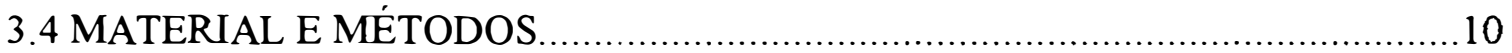

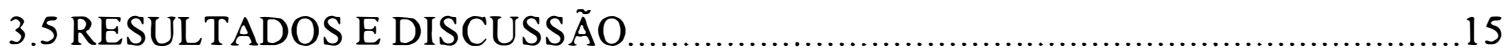

3.6 CONCLUSOัES

4 EFEITOS DE REGULADORES VEGETAIS NO DESENVOLVIMENTO E PRODUTIVIDADE DA CULTURA DA BATATA (Solamum tuberosum L., cv Achat),

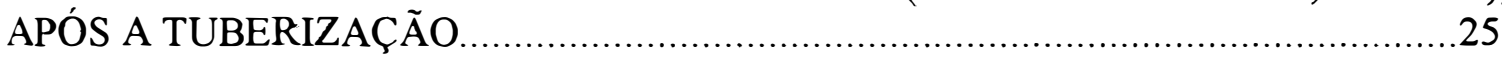

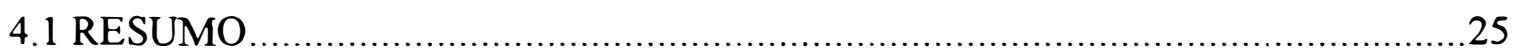

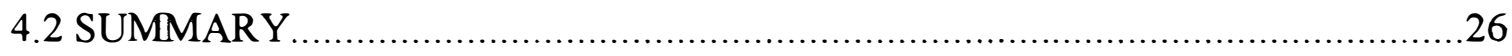

4.3 INTRODUÇÃO

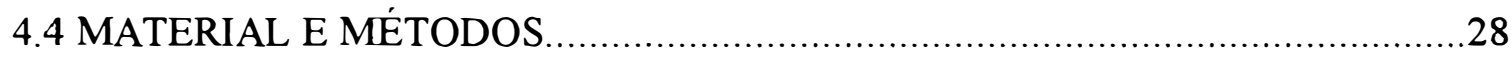

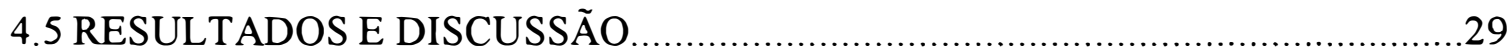


4.6 CONCLUSÕES

5 EFEITOS DA APLICAÇÃO DE REGULADORES VEGETAIS NO TEOR DE CARBOIDRATOS SOLÚVEIS TOTAIS E PRODUÇÃO FINAL DE TUBÉRCULOS DE BATATA (Solanum tuberosum L., cv Achat), APÓS A TUBERIZAÇÃO

5.1 RESUMO

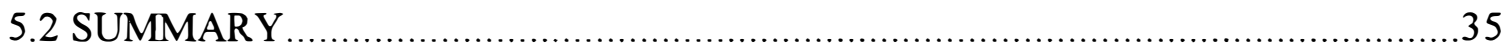

5.3 INTRODUÇÃO

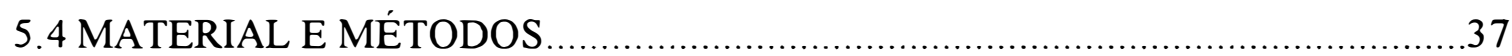

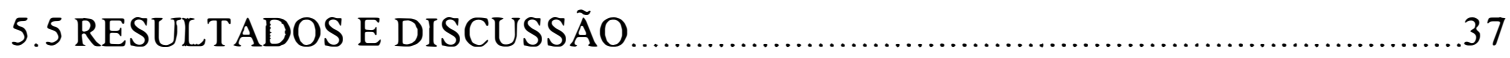

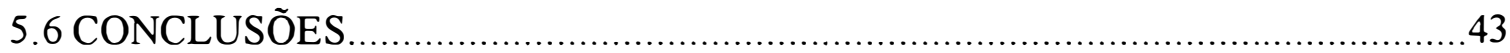

6 EFEITOS DE RETARDADORES DE CRESCIMENTO NO DESENVOLVIMENTO E PRODUTIVIDADE DA CULTURA DA BATATA (Solanum tuberosum L., cv

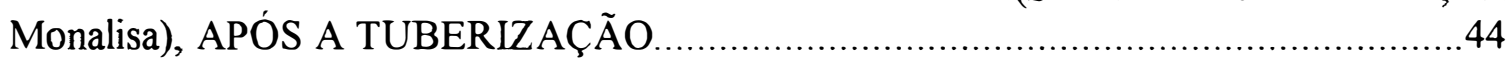

6.I RESUMO

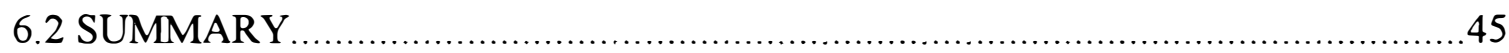

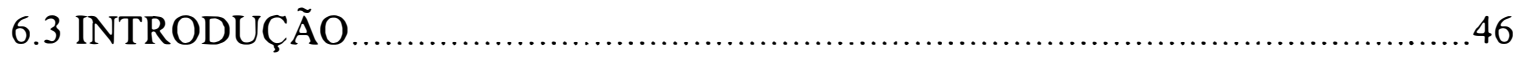

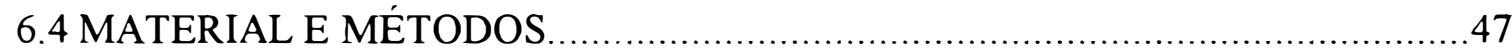

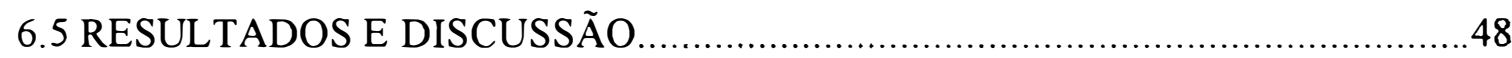

6.6 CONCLUSÕES

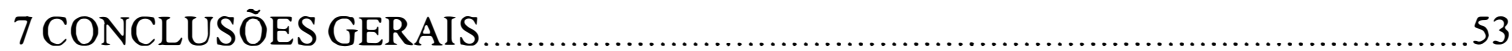

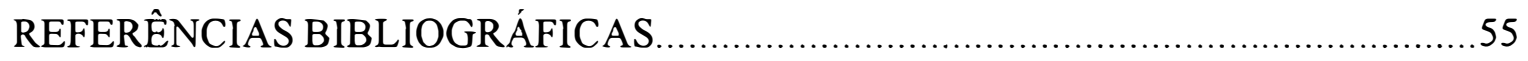




\title{
EFEITOS DE REGULADORES VEGETAIS APLICADOS NA CULTURA DA BATATA (Solanum tuberosum L.), APÓS A TUBERIZAÇÃO: ASPECTOS FISIOLÓGICOS E DE PRODUÇÃO
}

\author{
Autor : Silvio Tavares \\ Orientador: Prof. Dr. Antonio Augusto Lucchesi
}

\section{RESUMO}

O presente trabalho foi conduzido em 1997 e 1998, sob condições de campo, em plantação comercial de batata (Solamum tuberosum L.), com o objetivo de se avaliar os principais aspectos fisiológicos e de produção da cultura, sob a influência da ação de reguladores vegetais. No primeiro ano, utilizando-se cultivar de ciclo longo (Achat), foram aplicados os reguladores vegetais: ácido giberélico $\left(\mathrm{GA}_{3}\right) 15 \mathrm{mg} . \mathrm{L}^{-1}$; ácido naftalenacético (NAA) $15 \mathrm{mg} . \mathrm{L}^{-1}$; ácido (2-cloroetil)fosfônico (CEPA) 200 e $400 \mathrm{mg} . \mathrm{L}^{-1}$;

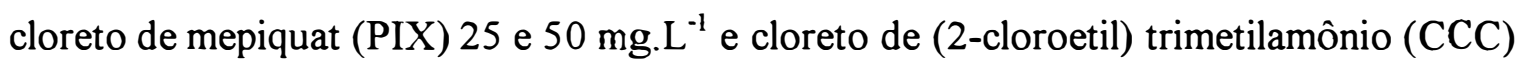
250 e $500 \mathrm{mg}$. $\mathrm{L}^{-1}$, além do controle. No segundo ano, baseado nos resultados do trabalho anterior, utilizou-se cultivar de ciclo curto (Monalisa), no qual, foram aplicados via foliar, somente os retardadores de crescimento cloreto de mepiquat (PIX) e cloreto de (2cloroetil) trimetilamônio (CCC) nas concentrações: 25,50 e $100 \mathrm{mg} \cdot \mathrm{L}^{-1}$ e 250 , 500 e $1000 \mathrm{mg} . \mathrm{L}^{-1}$, respectivamente, além do controle.

Quatro trabalhos foram realizados, no primeiro, verificou-se através da análise de crescimento, que os retardadores de crescimento (PIX e CCC) e o promotor NAA, induziram maior índice de área foliar, taxa de crescimento relativo foliar e taxa de produção de matéria seca (TPMS), no segundo período avaliado. O CCC $250 \mathrm{mg} . \mathrm{L}^{-1} \mathrm{e}$ NAA $15 \mathrm{mg} . \mathrm{L}^{-1}$, apresentaram maior TPMS na fase final do ciclo. A taxa assimilatória líquida (TAL), permaneceu constante até o final do ciclo, nos tratamentos com CCC e 
NAA. No segundo trabalho, os reguladores vegetais nas concentrações aplicadas, não afetaram o desenvolvimento da área foliar, o número de hastes, número de entrenós e tubérculos por planta. O comprimento dos estolões foi reduzido com $\mathrm{GA}_{3}$ e aumentado com a aplicação de NAA.

No terceiro trabalho, determinaram os teores de carboidratos em folhas e tubérculos, mostrando a ação dos reguladores vegetais quanto à partição de assimilados. No quarto trabalho, avaliou-se área foliar, massa de matéria seca, peso específico foliar, teores de clorofila e teores de amido nos tubérculos. $\mathrm{O}$ parâmetro peso específico foliar permitiu detectar a ação dos retardadores vegetais aplicados na parte aérea, o que, não se verificou na área foliar.

Os retardadores vegetais aplicados, aumentaram o teor de sólidos solúveis ( ${ }^{\circ}$ Brix) nos tubérculos de plantas tratadas. $\mathrm{O}$ aumento na porcentagem de tubérculos sementes do tipo I para o cultivar Achat, com o uso dos reguladores vegetais foi de: $53 \%$ com $\mathrm{GA}_{3}$; $62 \%$ com PIX 25; 67\% com CCC 500; 46\% com PIX 50 e 37\% com CCC 250. O aumento no tipo II, foi de $47 \%$ com NAA e $33 \%$ com CCC 250 . O aumento da porcentagem nos tubérculos do tipo III, ocorreu somente com o CCC250.

Os parâmetros que melhor expressaram a ação dos reguladores vegetais aplicados foram: peso específico foliar, teor de carboidratos solúveis em folhas e tubérculos, taxa de crescimento relativo (TCR), taxa de produção de matéria seca (TPMS) e taxa assimilatória líquida (TAL).

Nas condições de outono-inverno, os reguladores vegetais aplicados em baixas concentrações, estimulam a produção final de tubérculos. 


\title{
EFFECTS OF GROWTH REGULATORS IN THE POTATO CROP (Solanum tuberosum L.), AFTER TUBERIZATION: PHYSIOLOGICAL AND PRODUCTION ASPECTS
}

\author{
Author: Silvio Tavares \\ Adviser: Prof. Dr. Antonio Augusto Lucchesi
}

\section{SUMMARY}

The present work was driven in 1997/98, under field conditions, in commercial potato crop (Solanum tuberosum L.), with the objective of evaluating physiologic aspects of the crop, under the influence of the growth regulators. In the first year, being used cultivar of long cycle (Achat), were applied the growth regulators: gibberellic acid $\left(\mathrm{GA}_{3}\right)$ $15 \mathrm{mg} . \mathrm{L}^{-1}$; naphthalene acetic acid (NAA) 15 mg.L ${ }^{-1}$; (2-chloroethyl) phosphonic acid (CEPA) 200 and $400 \mathrm{mg} . \mathrm{L}^{-1}$; mepiquat chloride (PIX) 25 and $50 \mathrm{mg} . \mathrm{L}^{-1}$ and (2chloroethyl) trimethylammonium chloride (CCC) 250 and 500 mg. $\mathrm{L}^{-1}$, besides the control. In the second year, based on the results of the previous work, it was used cultivar of short cycle (Monalisa), in which, were applied through spraying on leaves, only the growth retardants mepiquat chloride (PIX) and (2-chloroethyl) trimethylammonium chloride (CCC) in the concentrations: 25,50 and $100 \mathrm{mg} . \mathrm{L}^{-1}$ and 250,500 and $1000 \mathrm{mg} . \mathrm{L}^{-1}$, respectively, besides the control.

Four experiments were accomplished. In the first work, it was verified through the growth analysis, that the growth retardants (PIX and CCC) and the promoter NAA, induced larger leaf area index, relative growth leaf rate (RGLR) and dry matter production rate (DMPR) in the second appraised period. CCC $250 \mathrm{mg} . \mathrm{L}^{-1}$ and NAA 15 mg. $\mathrm{L}^{-1}$, presented larger DMPR in the last phase of the cycle. The net assimilation rate (NAR), stayed constant until the end of the cycle, with CCC and NAA treatments. In the second work, the growth regulators, didn't affect the development of the leaf area, the 
number of stems, internodes number and number of tubers per plant. $\mathrm{GA}_{3}$ increased the height of the plants. $\mathrm{GA}_{3}$ reduced and NAA increased stolons length.

In the third work, the carbohydrates content obtained in leaves and tubers, showed the action of the growth regulators, with relationship to the partitioning of assimilates. In the fourth work, leaf area, dry weight matter leaf, was evaluated. The leaf specific weight, chlorophyll and starch content in the tubers were also evaluated. The leaf specific weight parameter allowed us to detect the action of the growth retardants in the shoots, in which, wasn't possible check in the leaf area.

The growth retardants spraying, increased the soluble solids ( $\left({ }^{\circ} \mathrm{Brix}\right)$ in the tubers of all plants. Percentage of type I, was increase of seeds tubers for cultivar Achat: $53 \%$ for $\mathrm{GA}_{3}\left(15 \mathrm{mg} . \mathrm{L}^{-1}\right) ; 62 \%$ for PIX (25 mg. $\left.\mathrm{L}^{-1}\right) ; 67 \%$ for CCC (500 mg. $\left.\mathrm{L}^{-1}\right) ; 46 \%$ for PIX (50 mg. $\left.\mathrm{L}^{-1}\right)$ and $37 \%$ for CCC (250 mg. $\left.\mathrm{L}^{-1}\right)$. NAA (15 mg. $\left.\mathrm{L}^{-1}\right)$ and CCC $\left.250 \mathrm{mg} . \mathrm{L}^{-1}\right)$, increased $47 \%$ and $33 \%$ type II of the seed tubers respectivity and CCC $250 \mathrm{mg} . \mathrm{L}^{-1}$, increased type III of the tubers.

The parameters (specific leaf weight, carbohydrate contents, relative growth rate, dry matter production rate and net assimilation rate), were effective to study growth regulators action on potato crop.

In the autumn-spring conditions, low concentrations of growth regulators can produce stimulatory effects on tubers yield. 


\title{
1 INTRODUÇÃO
}

\begin{abstract}
Algumas plantas cultivadas no Brasil já atingiram estágios de evolução que exigem elevado nível técnico para alcançar melhor produtividade (Castro, 1997 $)$. Entre essas culturas encontra-se a da batata (Solanum tuberosum L.) que não se apresenta condicionada por limitações de ordem nutricional e hídrica, além de ser protegida adequadamente com defensivos. A importância da cultura da batata, tem aumentado nos dias atuais, principalmente pela excelente fonte alimentar e também pelo aproveitamento de áreas de renovação de canaviais.

Trata-se de uma planta herbácea, com altura variável de 0,5 m e caules angulosos. As folhas são simples, recortadas, com dois a quatro pares de lóbulos primários laterais e um terminal. O seu tamanho tem especial importância na caracterização dos cultivares, a parte subterrânea é formada por raizes e estolões, sendo que na extremidade dos estolões aparecem os tubérculos.
\end{abstract}

No Brasil a cultura da batata ocupa área de cultivo em torno de 188.000 ha, com produtividade média de 14,7 ton.ha ${ }^{-1}$, sendo que as áreas de produção estão concentradas nas regiões Sul e Sudeste (Anuário Estatístico do Brasil, 1996). No Estado de São Paulo, as principais regiões produtoras são Sorocaba e Campinas, representando em torno de $90 \%$ da área total. São regiões consideradas cinturões verdes onde a batata vem sendo cultivada principalmente em áreas de renovação da cultura de cana-de-açúcar. A produtividade paulista é de 19,3 ton.ha-1 (Anuário Estatístico do Brasil, 1996).

A necessidade de maior produtividade faz com que todos os setores envolvidos na 
cadeia produtiva estabeleçam pesquisas que proporcionem condições favoráveis para o desenvolvimento da cultura. Nessas condições, o emprego de reguladores vegetais pode mostrar-se altamente compensador.

Regulador vegetal é um composto orgânico que, em pequenas quantidades promove, inibe ou modifica qualitativamente o crescimento e o desenvolvimento das plantas ( Castro, 1997' ; Hopkins, 1995). Os principais reguladores vegetais utilizados neste trabalho, pertencem aos grupos das auxinas, giberelinas, retardadores e etileno.

$\mathrm{O}$ objetivo do presente trabalho, é analisar os principais aspectos fisiológicos e bioquímicos, bem como a produtividade final da cultura de batata, sob a influência da aplicação de regulădores vegetais, após a tuberização.

\footnotetext{
${ }^{1}$ Informações Agronômicas, n. 78. junho/97.
} 


\section{REVISÃO DE LITERATURA}

$\mathrm{O}$ crescimento e desenvolvimento vegetal está diretamente relacionado com as substâncias produzidas pelas plantas (Felippe, 1979). Nickell (1988) destacou a importância da utilização de compostos sintéticos com funções análogas aos hormônios, devido à valorização dos produtos agrícolas tratados com estes compostos. Ainda definiu reguladores vegetais como sendo compostos naturais ou sintéticos que aplicados diretamente em uma planta alvo visando alterar processos biológicos, levam a melhoria de qualidade, produção ou facilidade de colheita. Castro et al. (1996) sugeriram a aplicação de ácido giberélico em cultivos para a produção de tubérculos-semente, para a obtenção de maior número de tubérculos menores.

Marchner et al. (1984) estudando a taxa de crescimento de tubérculos individualizados, observaram correlação positiva de ácido indolilacético para tubérculos da mesma idade com taxas de crescimento diferentes. A correlação entre idade do tubérculo e matéria fresca correspondente foi negativa para ácido indolilacético endógeno. Esses dados suportam que o conteúdo de auxina endógena pode ser o fator responsável pelo controle da taxa de crescimento ( atividade de dreno) de tubérculos individuais.

O máximo crescimento vegetativo da planta de batata cultivar Achat, foi verificado por Paula (1986) entre 40 e 50 dias após a emergência, sendo que desta fase até o final do ciclo, ocorreu o crescimento dos tubérculos. Essas informações levaram à escolha da época de aplicação dos reguladores vegetais uma vez que, a força de dreno dos tubérculos provavelmente seria maior nesse período. Vários autores relacionaram 
ganho de produção com o aumento do número de hastes, folhas e tubérculos por planta (Reddy et al., 1991; Metzer, 1984; Soares et al., 1982; Shadeque \& Pandita, 1982). Juzl (1994) relacionou a máxima produção de tubérculos com índice de área foliar (IAF) de 40 a $50 \mathrm{dm}^{2} \cdot \mathrm{m}^{-2}$ em plantas de batata.

Trabalhando com os cultivares Bintje, aos 30 dias da germinação e Baronesa aos 40 dias da germinação, Soares et al.(1982) verificaram que a aplicação de cloreto de mepiquat na concentração de 50 g i.a.ha ${ }^{-1}$ aumentou o número de tubérculos por planta $\mathrm{e}$ uniformidade no tamanho, diminuindo o número de tubérculos pequenos e com excessivas dimensões e promovendo aumento médio de $12 \%$ na produção.

Cruz (1982) verificou aumento de $19,1 \%$ na produção de tubérculos comerciais no cultivar Omega, mesmo não tendo diferenças significativas para altura, área foliar e produção total. Análises da porcentagem de amido não acusaram diferenças significativas para os tratamentos utilizados $\left(12,5 ; 25,0\right.$ e 50,0 g i.a. ha $\left.{ }^{-1}\right)$, indicando que a aplicação do cloreto de mepiquat não interferiu na qualidade da batata.

Pieterse et al. (1982) não conseguiram resultados positivos quando utilizaram cloreto de mepiquat nas concentrações de $0,15,30$ e 60 g.i.a.ha $^{-1}$ aos 30,50 e 70 dias após o plantio (DAP). Outros reguladores vegetais como a hidrazida maleica e daminozide também foram pesquisados na cultura da batata, porém os resultados obtidos não foram promissores (Yada et al., 1991; Schaupmeyer et al., 1985; Gowda \& Krishnappa, 1984).

Aplicações de ethephon nas concentrações de 6l, 122 e 183 g i.a.ha ${ }^{-1}$ no início da tuberização diminuíram a produção de tubérculos, sendo que as maiores concentrações aumentaram o número de tubérculos pequenos (Koller \& Hiller, 1988). Meltzer (1984) utilizando $150 \mathrm{ml} \cdot \mathrm{ha}^{-1}$ de ethephon em pulverização, observou aumento do número de tubérculos por planta para os cultivares que possuíam longo período de tuberização, sendo que o mesmo não ocorreu para cultivares precoces. $O$ ethephon em cultivares de 
longo período de tuberização aumentou o número de tubérculos do tipo III e reduziu o número de tubérculos do tipo $\mathrm{I}$.

Rex (1992) utilizou ethephon na concentração de $300 \mathrm{~g}$ i.a.ha ${ }^{-1}$; chlormequat 920 g i.a.ha ${ }^{-1}$ com uma segunda aplicação de 230 g i.a.ha ${ }^{-1}, 2$ semanas após a primeira; mistura de ethephon 156 g i.a.ha ${ }^{-1}$ com chlormequat 299 g i.a.ha ${ }^{-1}$. Todos os tratamentos reduziram a produção de tubérculos comerciais e aumentaram o número de tubérculos pequenos. Pulverizações com $340 \mathrm{mg} . \mathrm{L}^{-1}$ de ethephon e $250 \mathrm{mg} . \mathrm{L}^{-1}$ de paclobutrazol no início do florescimento foram estudadas por Zrust \& Mica (1992), os quais verificaram aumento na massa de matéria seca dos tubérculos para o ethephon e redução no conteúdo de amido no cultivar Darin (precoce) para o paclobutrazol.

A relação entre brotação e produção de tubérculos de batata no cultivar Russet Burbank foi verificada por Balaman \& Poovaiah (1985), sob condições de casa de vegetação, utilizando o paclobutrazol na concentração de $0,1 \%$. Essa concentração inibiu o alongamento do caule em $67 \%$, mas aumentou a massa de matéria seca dos tubérculos e diminuiu a massa da matéria seca da parte aérea.

Em experimento em condições de campo, Bodlaender et al. (1989) aplicaram ácido giberélico nas concentrações de 50 ou $100 \mathrm{~g}$ i.a.ha ${ }^{-1}$ em diferentes estádios de desenvolvimento da planta de batata. Verificaram que em aplicações no início da tuberização, ocorria alongamento de caules e estolões com retardamento fraco para o início da tuberização. Observou-se também aumento no número de tubérculos com tamanho de 28 a $45 \mathrm{~mm}$ (tipo III), sendo que a maior concentração de ácido giberélico produziu tubérculos longos e curvilíneos.

O controle da tuberização foi estudado por Langille \& Hepler (1992) onde plantas de batata cultivar Katahdin, crescendo sob condições não indutivas, receberam aplicações de chlormequat e ácido giberélico e após os tratamentos foram colocadas numa câmara ajustada para promover a indução. As plantas tratadas com chlormequat, nas condições 
não indutivas aumentaram de 2 a 3 vezes a porcentagem de tuberização em relação aos $25 \%$ do controle não induzido, aplicação de ácido giberélico em plantas sob condições de indução reduziram de $99 \%$ para $7 \%$ a resposta à indução de tuberização.

Mattar \& Abdul (1988), aplicaram ácido giberélico e chlormequat nas concentrações $25,50,100 \mathrm{mg} . \mathrm{L}^{-1}$ e 250,500 e $1000 \mathrm{mg} . \mathrm{L}^{-1}$, respectivamente, em plantas de batata, 2 semanas após o início da tuberização. $\mathrm{O}$ ácido giberélico aumentou e $\mathrm{O}$ chlormequat reduziu a altura da planta e o número de hastes por planta após 30 dias da aplicação.

Reddy et al. (1991) aplicaram misturas de reguladores vegetais (giberelinas, citocininas, auxinas e traços de nutrientes), nas concentrações de 0 a $101 . \mathrm{ha}^{-1} \mathrm{e}$ verificaram que a concentração de $7,51 . \mathrm{ha}^{-1}$ proporcionou aumento de produção de $43,68 \%$ em relação ao controle. Esse aumento foi relacionado com o aumento de brotações por haste, número de folhas e tubérculos por planta.

Shadeque \& Pandita (1982) verificaram que o aumento na concentração de chlormequat aplicado aos 50 ou 70 dias após o plantio, causava diminuição de altura e massa de matéria fresca. A concentração de $500 \mathrm{mg}$. $\mathrm{L}^{-1}$ de chlormequat aplicada aos 50 dias após o plantio (DAP) aumentou a produção e a proporção de tubérculos maiores.

Sekhon \& Singh (1985) observaram em experimento de campo aos 35 DAP que chlormequat aplicado nas concentrações de 300,600 e $900 \mathrm{ml}^{-h^{-1}}$, diminuiu a altura da planta. Entretanto, a concentração de $600 \mathrm{ml} \cdot \mathrm{ha}^{-1}$, aumentou a produção de tubérculos sementes. 


\title{
3 ANÁLISE QUANTITATIVA DE CRESCIMENTO NA CULTURA DE BATATA (Solanum tuberosum L cv Achat) SOB INFLUÊNCIA DE REGULADORES VEGETAIS, APÓS TUBERIZAÇÃO ${ }^{1}$
}

\author{
S. TAVARES ${ }^{2}$; A. A. LUCCHESI
}

Depto. de Ciências Biológicas - ESALQ/USP - CEP: 13418-900 - Piracicaba, SP.

\subsection{RESUMO}

O presente trabalho foi desenvolvido utilizando-se de alguns parâmetros da análise de crescimento, com a finalidade de determinar a ação de reguladores vegetais no crescimento de batata, cultivar Achat após a tuberização.

Foram aplicados aos 45 dias após o plantio, via foliar, os seguintes reguladores vegetais: ácido giberélico $\left(\mathrm{GA}_{3}\right)$ à $15 \mathrm{mg} . \mathrm{L}^{-1}$; ácido naftalenacético (NAA) à $15 \mathrm{mg} . \mathrm{L}^{-1}$; ácido (2-cloroetil) fosfônico (CEPA) à 200 e $400 \mathrm{mg} \cdot \mathrm{L}^{-1}$; cloreto de mepiquat (PIX) à 25 e $50 \mathrm{mg} . \mathrm{L}^{-1}$; cloreto de (2-cloroetil) trimetilamônio (CCC) à 250 e $500 \mathrm{mg} . \mathrm{L}^{-1}$; além do controle.

A análise quantitativa de crescimento foi realizada a cada período de 14 dias após a aplicação dos reguladores vegetais, com uma avaliação inicial. Foram colhidas as plantas de batata e determinadas a área foliar e massa de matéria seca produzida dos diferentes órgãos dessa cultura. Os resultados obtidos, mostraram que os reguladores vegetais nas concentrações utilizadas não afetam a área foliar e massa de matéria seca

\footnotetext{
${ }^{1}$ Parte da dissertação apresentada a ESALQ/USP em Fisiologia e Bioquímica de Plantas.

${ }^{2}$ Bolsista da CAPES, pós-graduando em Fisiologia e Bioquímica de Plantas - ESALQ/USP.
} 
foliar, mas aumentam a massa de matéria seca dos tubérculos de plantas tratadas com CCC $500 \mathrm{mg} . \mathrm{L}^{-1}$ e NAA $15 \mathrm{mg} \cdot \mathrm{L}^{-1}$ aos 42 dias após a aplicação.

A aplicação de CEPA na concentração de $400 \mathrm{mg} . \mathrm{L}^{-1}$, promoveu aumento na matéria seca nas hastes, diminuindo a massa de matéria seca dos tubérculos na fase final do ciclo da cultura (56 DAA).

Os parâmetros de análise de crescimento (taxa de crescimento relativo foliar, taxa de crescimento relativo, taxa de produção de matéria seca e taxa assimilatória líquida), mostraram-se eficientes na interpretação dos resultados obtidos pela ação dos reguladores vegetais.

Palavras chaves: Solanum tuberosum, reguladores vegetais, análise de crescimento.

\section{QUANTITATIVE ANAlysis OF PLANT GROWTH IN POTATO (Solanum tuberosum L. cv Achat), AS INFLUENCED BY GROWTH REGULATORS, AFTER TUBERIZATION}

\subsection{SUMMARY}

A field experiment was carried out with the objective of study the influence of growth regulators on development of potato (Solanum tuberosum L.) cultivar Achat, after tuberization.

The following products were applied 45 days after planting: (2-chloroethyl) phosphonic acid (CEPA) 200 and $400 \mathrm{mg} . \mathrm{L}^{-1}$; mepiquat chloride (PIX) 25 and $50 \mathrm{mg} . \mathrm{L}^{-1}$; (2-chloroethyl) trimethylammonium chloride (CCC) 250 and $500 \mathrm{mg} . \mathrm{L}^{-1}$; gibberellic acid $\left(\mathrm{GA}_{3}\right) 15 \mathrm{mg} . \mathrm{L}^{-1}$; naphthalene acetic acid (NAA) $15 \mathrm{mg} . \mathrm{L}^{-1}$ and check.

For the quantitative analysis of vegetative growth, plants to determining foliar area and dry matter production were picked up each 14 days from initial avaliation.

The results showed that concentrations used didn't affects leaf area and dry matter leaf production. CEPA $400 \mathrm{mg}^{-\mathrm{L}^{-1}}$ increased dry matter stem, but decreased dry 
matter tubers in the final cycle. CCC $500 \mathrm{mg} . \mathrm{L}^{-1}$ and NAA $15 \mathrm{mg} . \mathrm{L}^{-1}$, increased the dry matter tubers (42 DAA).

The growth analysis parameters (relative growth leaf rate, relative growth rate, dry matter production rate and net assimilation rate), were effective to interprete the effects of growth regulators. Higher net assimilation rate was observed in plants treated with CCC and NAA in the final cycle.

Keys words: Solanum tuberosum, growth regulators, plant growth analysis.

\subsection{INTRODUÇÃO}

Observando-se uma curva de crescimento de um vegetal em termos de área foliar ou massa de matéria seca, verifica-se que existe diferentes fases: um período inicial mais lento, seguido de uma fase de crescimento rápido e finalmente um decréscimo na acumulação de matéria seca ou na área foliar da planta (Magalhães, 1979). Felippe (1979a) relacionou crescimento a todas as mudanças quantitativas e desenvolvimento com o crescimento e mudanças de forma de uma planta.

O crescimento de uma planta pode ser medido através da análise quantitativa de crescimento obtendo-se dados mais precisos e vários estudos de produtividade vegetal, sob diferentes condições ambientais foram realizados (Blackman \& Wilson, 1951; Watson, 1952; Alvim \& Alvim, 1969; Buttery \& Buzzell, 1972 e Lucchesi \& Minami, 1980).

A utilização de reguladores vegetais em culturas econômicas tem sido de grande interesse e, portanto, a análise de crescimento vegetal tem-se mostrado como importante ferramenta na verificação dos efeitos desses produtos no crescimento e na produtividade final. 
Felippe (1979b) citou que o etileno inibe a expansão da folha, além de aumentar a síntese da enzima clorofilase, enquanto que o CCC pode reduzir a síntese de etileno nas plantas.

Dyson \& Humphries (1966) observaram redução na área foliar de plantas de batata devido aos efeitos de cloreto decloro colina (CCC). Cruz (1982) observou aumento de produção no cultivar Omega, mesmo não ocorrendo diferenças significativas na área foliar. Os niveis de auxinas endógenas são influenciados pela idade fisiológica da planta ou órgão (Valio, 1979). Juzl (1994) relacionou a máxima produção de tubérculos com índice de área foliar (IAF) entre 40 e $50 \mathrm{dm}^{2} \cdot \mathrm{m}^{-2}$ em plantas de batata.

O presente trabalho foi desenvolvido com a finalidade de verificar a ação dos reguladores vegetais como o ácido giberélico $\left(\mathrm{GA}_{3}\right)$, ácido naftalenacético (NAA), ácido 2-cloroetilfosfônico (CEPA), cloreto de mepiquat (PIX) e cloreto de (2-cloroetil) trimetilamônio (CCC), na cultura de batata, após tuberização.

\subsection{MATERIAL E MÉTODOS}

O experimento foi conduzido em condições de campo (Latossolo vermelho amarelo), com altitude de $580 \mathrm{~m}$ e localizada no Sítio Roseira, município de Sumaré, Estado de São Paulo, durante o período de inverno.

Utilizou-se o cultivar Achat (Solanum tuberosum L.) sendo o plantio feito em nível, no espaçamento $0,80 \mathrm{~m}$ entre linhas e $0,30 \mathrm{~m}$ entre plantas. $O$ ensaio constou de nove tratamentos com três repetições totalizando 27 parcelas. Cada parcela constituiu-se de quatro linhas com 5,0 m de comprimento, totalizando $16,0 \mathrm{~m}^{2}$. Todas as parcelas foram isoladas por bordaduras constituídas por três linhas de plantas de batata.

Os reguladores vegetais foram aplicados através de pulverizações aos 45 dias após o plantio (DAP), com barra de pulverização com quatro metros de comprimento e bicos cônicos (80.03), espaçados em 0,50 m entre si, utilizando-se 400 litros de solução por hectare. Os tratamentos efetuados e suas respectivas concentrações estão relacionados na TABELA 1. 
TABELA 1 - Relação dos reguladores vegetais e suas respectivas concentrações aplicadas em cultura de batata. cultivar Achat.

\begin{tabular}{lc}
\hline Tratamentos & Concentrações $\left(\mathrm{mg.}^{-1}\right)$ \\
\hline Controle & - \\
Ácido giberélico $\left(\mathrm{GA}_{3}\right)$ & 15 \\
Ácido 2-cloroetil fosfônico (CEPA) & 200 \\
Ácido 2-cloroetil fosfônico (CEPA) & 400 \\
Cloreto de mepiquat (PIX) & 25 \\
Cloreto de mepiquat (PIX) & 50 \\
Cloreto (2-cloroetil)trimetilamônio (CCC) & 250 \\
Cloreto (2-cloroetil)trimetilamônio (CCC) & 500 \\
Ácido naftalenacético (NAA) & 15 \\
\hline
\end{tabular}

Efetuaram-se cinco avaliações durante o ensaio após a aplicação dos reguladores vegetais com períodos de 14 dias, obtendo-se: área foliar e massa de matéria seca de cada parcela.

Determinou-se a área foliar $\left(\mathrm{dm}^{2}\right)$ das plantas amostradas, utilizando-se o integrador de área foliar ("Area meter-3100") em todas a folhas destacadas.

Obteve-se a massa da matéria seca através da desidratação de todos os órgãos da planta (folhas, hastes, raizes e tubérculos) até peso constante, em estufa à temperatura de $65^{\circ} \mathrm{C}$, sob ventilação forçada.

O delineamento estatístico adotado foi blocos casualizados com 9 tratamentos e 3 repetições.

Com as determinações da área foliar total e da massa de matéria seca total da planta de batata, procedeu-se as análises de variações para área foliar e massa de matéria seca (folhas, hastes, raizes e tubérculos) em intervalos de 14 dias e dos parâmetros de crescimento, de acordo com as recomendações de Radford (1967), Blackman (1968), Buttery \& Buzzell (1972) e Magalhães (1979).

Os parâmetros analisados foram:

a- Relação parte aérea/sistema radicular (RPAR).

Obtida através da equação: 


$$
\text { RPAR }=\text { PSA/PSR, }
$$

onde:

PSA = massa em gramas da matéria seca da parte aérea da planta;

PSR = massa em gramas da matéria seca do sistema radicular da planta.

Essa relação possibilita o estudo comparativo do desenvolvimento da parte aérea em relação ao desenvolvimento do sistema radicular e analisar os efeitos de diferentes tratamentos na planta em estudo.

b- Índice de área foliar (IAF).

Obtida através da equação:

$$
\mathrm{IAF}=\mathrm{AF} / \mathrm{S},
$$

onde:

$$
\begin{aligned}
\mathrm{AF} & =\text { área foliar da planta em } \mathrm{dm}^{2} ; \\
\mathrm{S} & =\text { área do solo disponivel à planta em } \mathrm{dm}^{2} .
\end{aligned}
$$

Esse índice avalia a velocidade com que a área foliar ocupa a área de solo disponivel à planta.

c- Razão de área foliar (RAF).

Obtida através da equação:

$\mathrm{RAF}=\mathrm{AF} / \mathrm{PS}, \mathrm{em}\left(\mathrm{dm}^{2} \cdot \mathrm{g}^{-1}\right)$,

onde:

$$
\begin{aligned}
& \mathrm{AF}=\text { área foliar da planta; } \\
& \mathrm{PS}=\text { massa de matéria seca total da planta } .
\end{aligned}
$$

A RAF permite avaliar o desenvolvimento da área foliar em relação ao desenvolvimento da planta como um todo, em termos de matéria seca produzida em cada amostragem. 
d- Taxa assimilatória líquida (TAL).

Obtida através da equação:

$T A L=P_{2}-P_{1} /\left(A_{2}-A_{1}\right) .\left(L A_{2}-L A_{1}\right) / t_{2}-t_{1}, e m\left(g \cdot d m^{-2} \cdot d i a^{-1}\right)$,

onde:

$\mathrm{P}_{2}=$ massa de matéria seca total da planta colhida na segunda amostragem;

$\mathrm{P}_{1}=$ massa de matéria seca total da planta colhida na primeira amostragem;

$\mathrm{L}=$ logaritmo neperiano;

$A_{2}=$ área foliar da planta no tempo $t_{2}$;

$A_{1}=$ área foliar da planta no tempo $t_{1} ;$

$t_{2}$ e $t_{1}=$ dias da segunda e primeira amostragem respectivamente.

A TAL refere-se as alterações na massa de matéria seca total da planta por unidade de área foliar e por unidade de tempo.

e- Taxa de crescimento relativo (TCR).

Obtida através da equação:

$\mathrm{TCR}=\mathrm{P}_{2}-\mathrm{P}_{1} / \mathrm{t}_{2}-\mathrm{t}_{1}, \mathrm{em}\left(\mathrm{g} \cdot \mathrm{g}^{-1} \cdot \mathrm{dia}^{-1}\right)$,

onde:

$\mathrm{P}_{2}=$ massa de matéria seca total da planta colhida na segunda amostragem;

$\mathrm{P}_{1}=$ massa de matéria seca total da planta colhida na primeira amostragem;

$t_{2}$ e $t_{1}=$ dias da segunda e primeira amostragem, respectivamente.

A TCR avalia o crescimento da planta em termos de matéria seca formada por unidade de tempo, em função da massa inicial.

f- Taxa de crescimento relativo foliar (TCRF).

Obtida através da equação:

$\mathrm{TCRF}=\mathrm{LA}_{2}-\mathrm{LA}_{1} / \mathrm{t}_{2}-\mathrm{t}_{1}, \mathrm{em} \mathrm{dm}^{2} \cdot \mathrm{dia}^{-1}$, 
onde:

$\mathrm{L}=$ logaritmo neperiano;

$A_{2}=$ área foliar da planta no tempo $t_{2}$;

$A_{1}=$ área foliar da planta no tempo $t_{1}$;

$t_{2}$ e $t_{1}=$ dias da segunda e primeira amostragem respectivamente.

A TCRF avalia a área foliar formada por unidade de tempo, correlacionada à área foliar inicial.

g- Taxa de produção de matéria seca (TPMS).

Obtida através da equação:

TPMS $=\left(P_{2}-P_{1}\right) / S /\left(t_{2}-t_{1}\right)$, em g.m ${ }^{-2} \cdot d i a^{-1}$,

onde:

$\mathrm{P}_{2}=$ massa de matéria seca total da planta colhida na segunda amostragem;

$\mathrm{P}_{1}=$ massa de matéria seca total da planta colhida na primeira amostragem;

$\mathrm{S}=$ área do solo disponível à planta $\mathrm{em} \mathrm{dm}^{2}$.

$t_{2}$ e $t_{1}=$ dias da segunda e primeira amostragem, respectivamente.

A TPMS também denominada de fotossintese líquida avalia o desenvolvimento da planta relacionando a quantidade de material orgânico acumulado, em função da área de solo ocupada pela planta, por unidade de tempo.

h- Índice de colheita (IC\%).

Obtida através da equação:

$\mathrm{IC} \%=\mathrm{PE} / \mathrm{PBT} .100$,

onde:

$\mathrm{PE}=$ produtividade econômica;

$\mathrm{PBT}=$ produtividade biológica total . 
O IC\% avalia o desenvolvimento dos tubérculos em relação ao desenvolvimento total da planta, portanto relacionando fonte/dreno.

\subsection{RESULTADOS E DISCUSSÃO}

Para facilitar a elaboração de Tabelas e Figuras utilizando-se dos dados obtidos, convencionou-se que a identificação dos reguladores vegetais ácido giberélico, ácido 2cloroetil fosfônico, cloreto de mepiquat, cloreto de (2-cloroetil) trimetilamônio, ácido naftalenacético e controle corresponderiam a $\mathrm{GA}_{3}$, CEPA, PIX, CCC, NAA e CONTROLE, respectivamente.

TABELA 2 - Efeito de reguladores vegetais na área foliar $\left(\mathrm{dm}^{2}\right)$ na cultura de batata cultivar Achat aos $14,28,42$ e 56 dias após a aplicação.

\begin{tabular}{lcccc}
\hline & \multicolumn{5}{c}{ Dias após a aplicação - Área foliar $\left(\mathrm{dm}^{2}\right)$} \\
\hline tratamentos & 14 & 28 & 42 & 56 \\
\hline CONTROLE & 63,1 & 36,33 & 51,96 & 6,05 \\
GA 15 & 66,19 & 47,16 & 55,83 & 7,52 \\
CEPA 200 & 68,79 & 38,73 & 45,63 & 11,44 \\
CEPA 400 & 40,09 & 34,93 & 42,33 & 19,4 \\
PIX 25 & 47,7 & 63,7 & 33,83 & 8,93 \\
PIX 50 & 58,56 & 58,93 & 49,33 & 5,69 \\
CCC 250 & 62,73 & 63,83 & 43,66 & 8,57 \\
CCC 500 & 49,5 & 55,66 & 43,26 & 5,43 \\
NAA 15 & 61,66 & 66,16 & 47,53 & 11,89 \\
\hline F (trat) & $0,87 \mathrm{n} \mathrm{s}$ & $2,33 \mathrm{n} \mathrm{s}$ & $0,65 \mathrm{n} \mathrm{s}$ & $1,56 \mathrm{n} \mathrm{s}$ \\
\hline CV (\%) & 31,05 & 27,68 & 29,5 & 64,71 \\
ns não significativo. & \multicolumn{4}{|r}{}
\end{tabular}

Analisando-se os dados da TABELA 2, verificou-se que não houve variação significativa na área foliar $\left(\mathrm{dm}^{2}\right)$ entre os tratamentos em todas as avaliações realizadas; resultado semelhante foi encontrado por Cruz(1982). Nota-se porém, que aos 14 DAA, os tratamentos com CCC 250 e NAA apresentaram o dobro da área foliar em relação ao controle, o mesmo ocorreu aos 56 DAA, com NAA e CEPA 200. Entretanto, Dyson \& Humphries (1966) observaram redução na área foliar de plantas tratadas com CCC. Os dados suportam afirmar que as concentrações utilizadas e a época de aplicação não afetam o desenvolvimento foliar da planta em estudo. 
De acordo com Magalhães (1979), verificou-se decréscimo na área foliar na cultura de batata. A redução na área foliar com o tratamento CEPA 400 observada aos 14 DAA, comparada com a área foliar do tratamento CCC 250 que foi semelhante ao controle, está de acordo com Felippe (1979b), onde o etileno inibiu a expansão foliar e o CCC reduziu a síntese de etileno nas plantas tratadas. O tratamento NAA apresentou maior área foliar em relação ao controle aos 28 DAA e segundo Válio (1979), a idade fisiológica da planta pode ser influenciada quanto ao nível de auxina endógena.

Com relação a massa de matéria seca em folhas (TABELA 3), verificou-se que as aplicações com reguladores vegetais não diferiram do controle na primeira avaliação aos 14 dias após a aplicação. As diferenças ocorreram entre as aplicações com CEPA 200, CEPA 400 e PIX 25.

TABELA 3 - Efeito de reguladores vegetais na massa de matéria seca (g) de folhas na cultura de batata cultivar Achat. aos 14, 28, 42 e 56 dias após a aplicação (DAA).

\begin{tabular}{lcccc}
\hline & \multicolumn{1}{c}{ Dias após a aplicação - massa de matéria seca - folhas (gramas) } \\
\hline tratamentos & 14 & 28 & 42 & 56 \\
\hline CONTROLE & $20,52 \mathrm{ab}$ & 21,58 & 14,36 & $6,35 \mathrm{~b}$ \\
GA $_{3} 15$ & $17,20 \mathrm{ab}$ & 18,51 & 15,83 & $7,37 \mathrm{~b}$ \\
CEPA 200 & $25,67 \mathrm{a}$ & 12,39 & 15,55 & $8,95 \mathrm{~b}$ \\
CEPA 400 & $14,38 \mathrm{~b}$ & 13,04 & 14,38 & $17,49 \mathrm{a}$ \\
PIX 25 & $15,39 \mathrm{~b}$ & 22,11 & 10,13 & $7,12 \mathrm{~b}$ \\
PIX 50 & $21,42 \mathrm{ab}$ & 23,74 & 13,72 & $5,92 \mathrm{~b}$ \\
CCC 250 & $22,97 \mathrm{ab}$ & 23,03 & 12,81 & $5,85 \mathrm{~b}$ \\
CCC 500 & $19,68 \mathrm{ab}$ & 24,11 & 10,55 & $4,92 \mathrm{~b}$ \\
NAA 15 & $16,84 \mathrm{ab}$ & 21,26 & 16,61 & $7,79 \mathrm{~b}$ \\
\hline F (trat) & $4,07 *$ & $3,14 \mathrm{n} \mathrm{s}$ & $2,61 \mathrm{n} \mathrm{s}$ & $11,88 *$ \\
\hline CV (\%) & 16,45 & 21,67 & 17,55 & 23,7 \\
\hline ns não significativo. & & & &
\end{tabular}

A aplicação com CEPA 200 apresentou a maior massa de matéria seca enquanto houve decréscimo na massa de matéria seca com as aplicações com CEPA 400 e PIX 25. Aos 28 e 42 dias após a aplicação, não houve significância estatística entre os tratamentos realizados. Aos 56 dias, a aplicação com CEPA 400 apresentou massa de 
matéria seca significativa em relação aos demais tratamentos efetuados. Houve tendência de decréscimo no acúmulo de matéria seca após a tuberização (Magalhães, 1979), durante o período avaliado.

Em termos de massa de matéria seca em hastes (TABELA 4) notou-se aos 42 dias, diferenças significativas com as aplicações com CEPA e NAA, evidenciando-se assim o efeito do etileno em relação à auxina.

Obteve-se incremento significativo para massa de matéria seca em hastes aos 56 dias após a aplicação com CEPA 400, o qual diferiu significativamente dos tratamentos com CEPA 200, PIX 25, CCC 500, NAA 15 e controle.

TABELA 4 - Efeito de reguladores vegetais na massa de matéria seca (g) em hastes na cultura de batata cultivar Achat, aos 1+. 28, 42 e 56 dias após a aplicação.

\begin{tabular}{lcccc}
\hline & \multicolumn{4}{c}{ Dias após a aplicação - massa de matéria seca de hastes (gramas) } \\
\hline tratamentos & 14 & 28 & 42 & 56 \\
\hline CONTROLE & 14,27 & 13,22 & $12,15 \mathrm{ab}$ & $7,80 \mathrm{~b}$ \\
GA 15 & 16,98 & 15,45 & $14,42 \mathrm{ab}$ & $8,19 \mathrm{ab}$ \\
CEPA 200 & 16,9 & 8,31 & $10,12 \mathrm{~b}$ & $6,27 \mathrm{~b}$ \\
CEPA 400 & 10,82 & 10,33 & $10,37 \mathrm{~b}$ & $13,35 \mathrm{a}$ \\
PIX 25 & 14,69 & 14,09 & $10,46 \mathrm{ab}$ & $6,48 \mathrm{~b}$ \\
PIX 50 & 14,86 & 14,64 & $12,28 \mathrm{ab}$ & $11,51 \mathrm{ab}$ \\
CCC 250 & 14,93 & 14,94 & $15,76 \mathrm{ab}$ & $8,67 \mathrm{ab}$ \\
CCC 500 & 15,4 & 15,81 & $12,35 \mathrm{ab}$ & $7,34 \mathrm{~b}$ \\
NAA 15 & 13,74 & 15,78 & $17,16 \mathrm{a}$ & $7,52 \mathrm{~b}$ \\
\hline F (trat) & $0,68 \mathrm{n} \mathrm{s}$ & $2,10 \mathrm{n} \mathrm{s}$ & $3,45 *$ & $4,75 *$ \\
\hline CV (\%) & 25,89 & 23,31 & 18,18 & 21,41 \\
\hline ns não significativo & \multicolumn{4}{l}{} \\
significativo ao nivel de 5\% de probabilidade & & &
\end{tabular}

Comparando-se com os dados de massa de matéria seca em folhas (TABELA 3), a qual apresentou incremento aos 56 dias após a aplicação e decréscimo na massa de matéria seca dos tubérculos (TABELA 5), pode-se afirmar que os compostos orgânicos resultantes do processo fotossintético acumularam-se nas hastes.

Observou-se diferenças significativas para massa de matéria seca de tubérculos entre as aplicações realizadas com reguladores vegetais em todas as avaliações (TABELA 
5). Aos 14 DAA, verificou-se com a aplicação com CEPA 200 a maior massa de matéria seca, diferindo da aplicação com PIX 50 que apresentou a menor massa de matéria seca. Observa-se assim, o efeito de um acelerador da senescência (CEPA) aumentando a força de dreno dos tbérculos e de um retardador de crescimento (PIX) retardando a força de dreno dos tubérculos. Aos 28 dias notou-se que a aplicação com CEPA 200 apresentou a menor massa de matéria seca quando comparada com as aplicações com PIX 25, PIX 50 e CCC 500. Aos 42 dias, somente as aplicações com CCC 500 e NAA 15, apresentaram massa de matéria seca significativa em relação ao controle.

TABELA 5 - Efeito de reguladores vegetais na massa de matéria seca (g) em tubérculos na cultura de batata cultivar Achat, aos 14, 28, 42 e 56 dias após a aplicação.

\begin{tabular}{|c|c|c|c|c|}
\hline & \multicolumn{4}{|c|}{ Dias após a aplicação - massa de matéria seca de tubérculos (gramas) } \\
\hline tratamentos & 14 & 28 & 42 & 56 \\
\hline CONTROLE & $26,90 \mathrm{ab}$ & $93,46 \mathrm{ab}$ & $90,90 \mathrm{c}$ & $149,86 \mathrm{ab}$ \\
\hline $\mathrm{GA}_{3} 15$ & $24,76 \mathrm{ab}$ & $80,00 \mathrm{ab}$ & $133,53 \mathrm{abc}$ & $145,68 \mathrm{ab}$ \\
\hline CEPA 200 & $40,70 \mathrm{a}$ & $52,46 \mathrm{~b}$ & $128,03 \mathrm{abc}$ & $142,63 \mathrm{ab}$ \\
\hline CEPA 400 & $24,50 \mathrm{ab}$ & $80,80 \mathrm{ab}$ & $141,73 \mathrm{abc}$ & $133,66 \mathrm{~b}$ \\
\hline PIX 25 & $31,30 \mathrm{ab}$ & 99,13 a & $104,90 \mathrm{bc}$ & $159,69 \mathrm{ab}$ \\
\hline PIX 50 & $17,00 \mathrm{~b}$ & $94,46 \mathrm{a}$ & $109,46 \mathrm{bc}$ & $166,13 \mathrm{ab}$ \\
\hline CCC 250 & $30,63 \mathrm{ab}$ & $88,40 \mathrm{ab}$ & $124,80 \mathrm{abc}$ & $182,00 \mathrm{a}$ \\
\hline CCC 500 & $26,90 \mathrm{ab}$ & $100,50 \mathrm{a}$ & 166,93 a & $148,13 \mathrm{ab}$ \\
\hline NAA 15 & $29,50 \mathrm{ab}$ & $72,76 \mathrm{ab}$ & $148,50 \mathrm{ab}$ & $156,63 \mathrm{ab}$ \\
\hline$\overline{F \text { (trat) }}$ & $2,88 *$ & $3,42 *$ & $4,32 *$ & $2,26 *$ \\
\hline$\overline{\mathrm{CV}}(\%)$ & 23,05 & 16,86 & 15,33 & 10,68 \\
\hline
\end{tabular}

Os índices de área foliar obtidos para cada período de 14 dias estão relacionados na FIGURA 1-A. Aos 14 dias após a aplicação (DAA), as concentrações com CEPA400, PIX25 e CCC500 apresentaram um IAF menor em relação ao controle, enquanto que nas demais aplicações o IAF foi maior que o controle. 


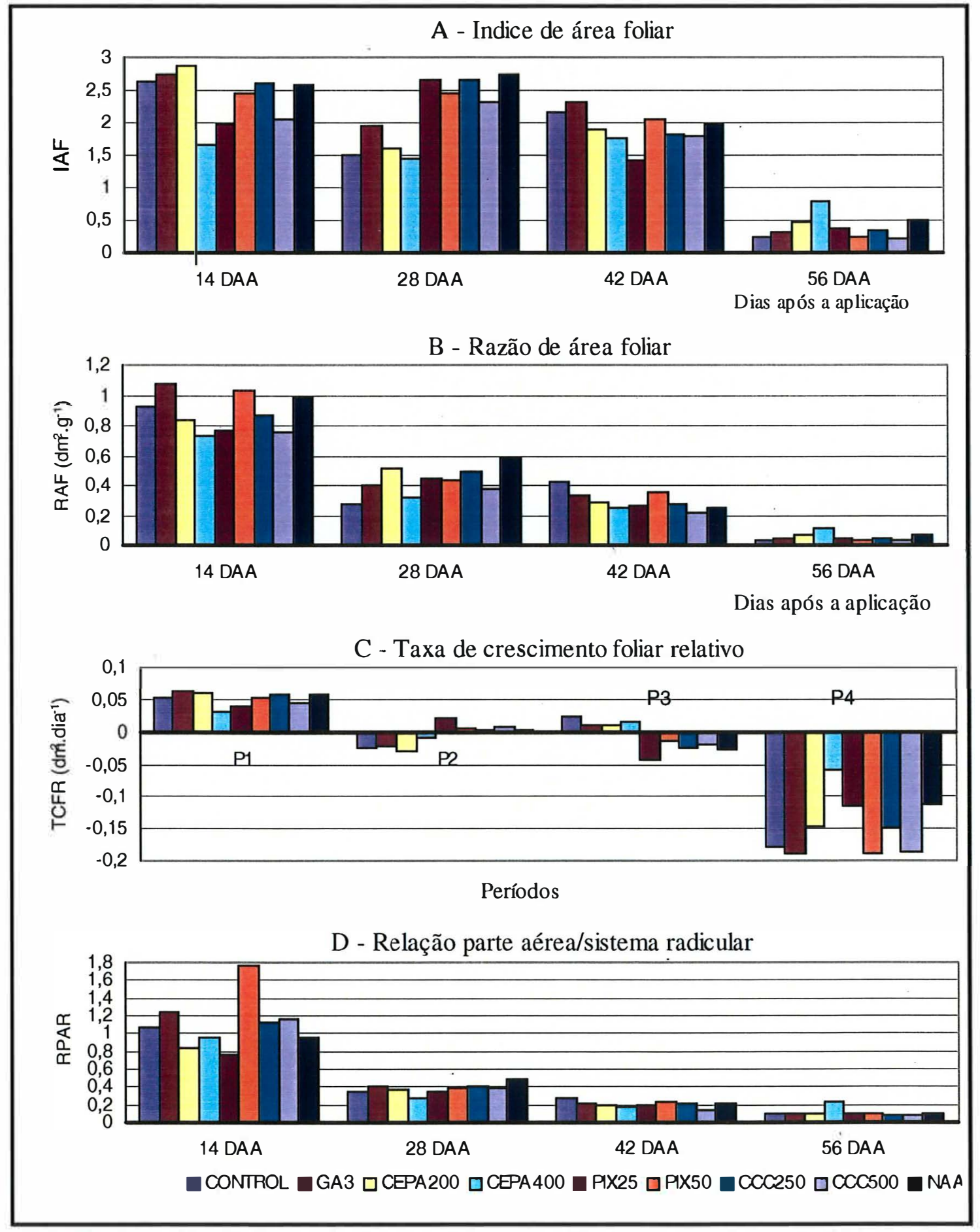

FIGURA 1 - Influência dos reguladores vegetais: (A) no índice de área foliar (IAF); (B) na razão de área foliar (RAF), (C) na taxa de crescimento foliar relativo (TCFR) no período (P) e (D) na relação parte aérea/sistema radicular, no cultivar Achat, aos 14, 28, 42 e 56 dias após aplicação. 

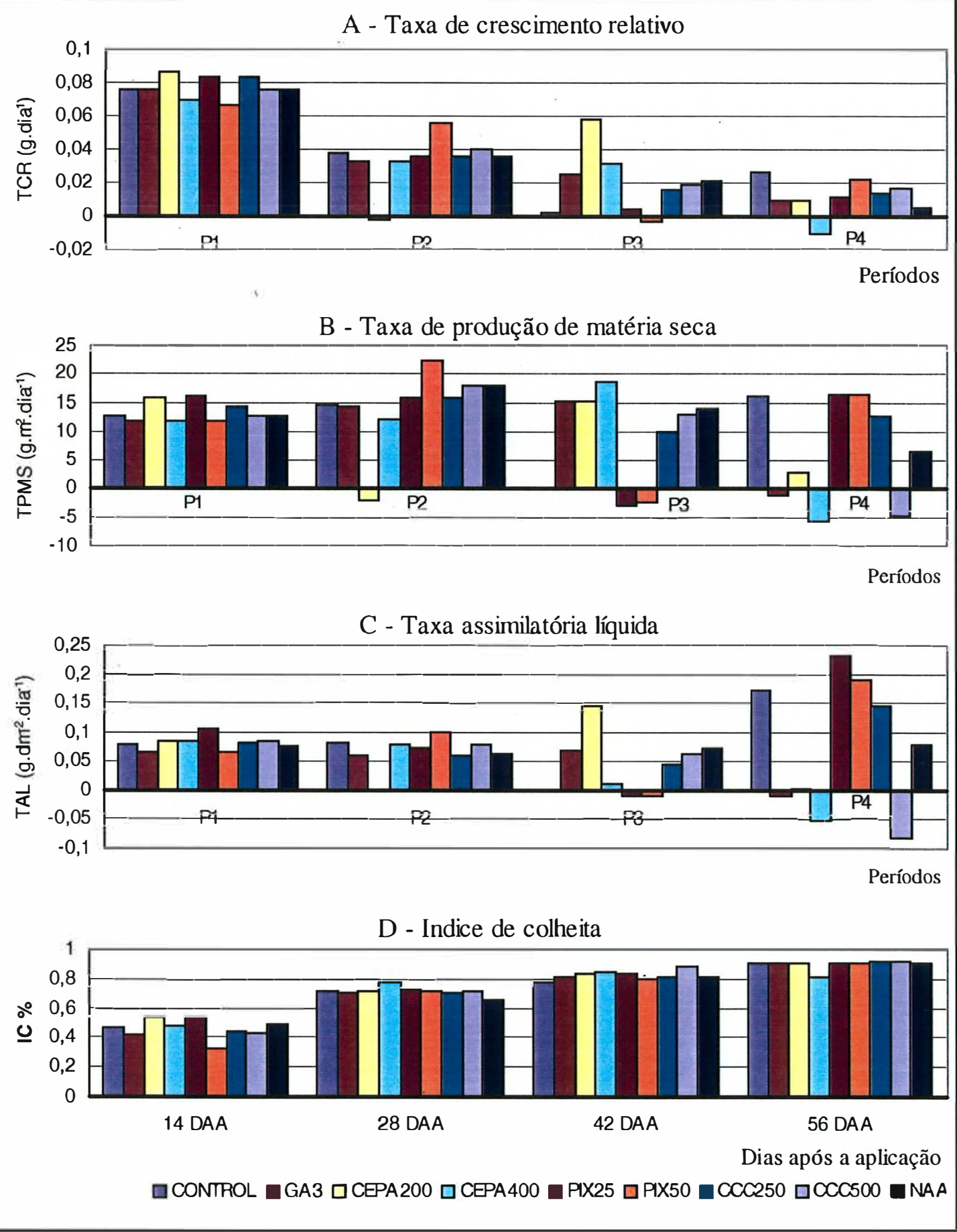

FIGURA 2 - Influência dos reguladores vegetais: (A) na taxa de crescimento relativo (TCR); (B) na taxa de produção de matéria seca (TPMS); (C) na taxa assimilatória líquida no período (P) e (D) no índice de colheita (IC\%), no cultivar Achat, aos 14, 28, 42 e 56 dias após a aplicação. 
Aos 28 DAA, as aplicações com CEPA apresentaram IAF em torno de 1,50, praticamente igual ao controle e nas aplicações com PIX, CCC e NAA o índice de área foliar (IAF) foi em torno de 2,50. O IAF para a aplicação com $\mathrm{GA}_{3}$ foi de 1,96. Verificou-se nesse periodo que tanto as plantas tratadas com promotores (NAA e GA G $_{3}$ quanto as com retardadores de crescimento (PIX e CCC), ocuparam a área de solo disponivel mais rapidamente quando comparadas ao controle. Após 42 DAA, o menor IAF obtido foi com a aplicação com PIX 50. Foram obtidos IAF semelhantes para as outras aplicações.

A concentração de auxina exógena (NAA) utilizada foi suficiente para obtenção de IAF em torno de 2,5 aos 28 dias após a aplicação, enquanto que o IAF obtido com o controle foi de 1,5. Os retardadores nas menores concentrações aplicadas, promoveram incremento no IAF semelhante à NAA. Esses dados indicam que os retardadores em estudo além de inibir a sintese de giberelinas endógenas, contribuíram para manter um nivel adequado de auxinas no periodo. Segundo Felippe (1979b), o efeito com CCC pode estar relacionado com a inibição da sintese de etileno. O efeito de maior relevância observado no terceiro período, foi com a maior concentração de PIX aplicada. As maiores produções de matéria seca obtidas aos 56 dias após o tratamento (TABELA 5), podem ser correlacionadas com os maiores índices de área foliar obtidos aos 28 dias após a aplicação dos retardadores de crescimento (PIX e CCC). Isso pode indicar que a resposta de produção de uma planta pode estar relacionada com periodos diferentes do qual se efetuou a análise de crescimento (Blackman \& Wilson, 1951; Alvim \& Alvim, 1969; Buttery \& Buzzel, 1972; Lucchesi \& Minami, 1980). Juzl (1994), relacionou máxima produção de tubérculos de batata com indice de área foliar.

A FIGURA 1-B, representa a razão da área foliar (RAF) com o desenvolvimento total da planta em termos de matéria seca produzida em cada avaliação. Aos 14 DAA, evidenciou-se maior RAF para as aplicações com GA $\mathrm{G}_{3}$ e PIX50, verificando-se assim um efeito estimulatório, principalmente, da giberelina no desenvolvimento da área foliar. Aos 28 DAA, todas as aplicações resultaram em RAF superior ao controle, justificando assim 
o maior IAF obtido aos 28 DAA (FIGURA 1-A). Destacou-se na última avaliação, razão de área foliar superior aos demais tratamentos, com a aplicação de CEPA 400, devido provavelmente, ao surgimento de novas brotações em função do final do efeito residual do produto.

Analisando-se a taxa de crescimento foliar relativo (TCFR), (FIGURA 1-C), observou-se dois períodos de crescimento para o controle, sendo o primeiro em torno de $0,05 \mathrm{dm}^{2} \cdot \mathrm{dia}^{-1} \mathrm{e}$ o segundo em torno de $0,02 \mathrm{dm}^{2} \cdot \mathrm{dia}^{-1}$. No primeiro período avaliado, obteve-se TCFR menor em relação ao controle, somente com as aplicações com CEPA 400 e PIX 25. No segundo período, foram obtidas TCFR semelhantes ao controle, com as aplicações com $\mathrm{GA}_{3}$, CEPA e PIX25, enquanto que nas aplicações com os retardadores de crescimento (PIX50 e CCC) e NAA obteve-se TCFR positivas, comprovando-se assim, a influência dos retardadores e promotores na capacidade fotossintética da planta, podendo refletir na taxa de produção de matéria seca (TPMS).

Através da relação parte aérea/sistema radicular (RPAR), verificou-se que a maior diferença entre os tratamentos realizados ocorreu aos 14 DAA. Os dados de menor RPAR foi para as aplicações com CEPA e PIX25, indicando desse modo, o início do transporte de carboidratos para o sistema radicular. As maiores RPAR ocorreram com as aplicações com PIX50 e CCC, mostrando os efeitos dos retardadores na exportação de matéria seca da parte aérea para o sistema radicular. Aos 28 DAA, notou-se menor RPAR com a aplicação com CEPA400 quando comparada ao controle. A RPAR obtida para todas as aplicações foram inferiores ao controle aos 42 DAA. Observou-se acúmulo de matéria seca na parte aérea, na aplicação com CEPA na maior concentração (FIGURA 1-D), aos 56 DAA.

Notou-se no primeiro período (FIGURA 2-A), efeito inibitório na taxa de crescimento relativo (TCR) com as maiores concentrações de CEPA e de PIX. No segundo período avaliado, os dados da TCR revelaram que a aplicação com CEPA200 promoveu a paralisação do seu crescimento relativo e com PIX 50 a TCR foi estimulada. No terceiro período as taxas de crescimento relativo obtidas com CEPA foram superiores ao controle, as quais provavelmente foram resultantes de brotações laterais. Houve 
também reduções na TCR para os tratamentos com PIX, enquanto que nas aplicações com CCC e NAA a TCR foi superior ao controle. No quarto período, a maior redução na TCR foi observada com a aplicação com CEPA 400.

A taxa de produção de matéria seca (TPMS) foi influenciada pelos os reguladores vegetais aplicados a partir do segundo período (FIGURA 2-B). Na aplicação com PIX50 verificou-se a maior TPMS, enquanto que na aplicação com CEPA200 a redução mostrou-se biológicamente significativa em relação aos demais tratamentos. Verificou-se no terceiro periodo, que as plantas tratadas com PIX e também o controle, não produziram carboidratos de reserva. Os demais tratamentos mantiveram TPMS acima de $10 \mathrm{~g} \cdot \mathrm{m}^{2} \cdot \mathrm{dia}^{-1}$, o que poderá refletir na produção final. No quarto período, os tratamentos com PIX e com CCC 250 apresentaram TPMS semelhante ao controle, enquanto que nas maiores concentrações de CEPA e CCC, além da aplicação com $\mathrm{GA}_{3}$ a produção de matéria seca foi reduzida.

A taxa assimilatória líquida (TAL), (FIGURA 2-C), no primeiro período observado não apresentou diferenças entre as aplicações com reguladores vegetais. Entretanto, no segundo período, a aplicação com CEPA200 apresentou TAL negativa, sugerindo que nesse período não houve produção de matéria seca e sim consumo das reservas acumuladas no primeiro período. Após o efeito verificado no segundo período da aplicação com CEPA, notou-se que a TAL apresentou no terceiro período o maior índice. As menores taxas assimilatória líquida no terceiro periodo, foram obtidas com PIX nas duas concentrações aplicadas. No quarto período observado, as maiores concentrações de CEPA e CCC, além da aplicação com $\mathrm{GA}_{3}$, apresentaram TAL negativa.

Através do índice de colheita (IC\%), pode-se correlacionar (FIGURA 2-D), a força de dreno dos tubérculos. Em relação ao controle, houve incremento de 17,39\% com a aplicação com CEPA200 e PIX25, aos 14 DAA. Nesse periodo, a aplicação com PIX50 teve decréscimo de 30,43\%. Aos 28 DAA, todas as aplicações com reguladores vegetais apresentaram IC\% semelhante. Aos 42 DAA, houve incremento de 10,38\% e $14,28 \%$ para as aplicações com CEPA400 e CCC500 respectivamente. A aplicação com 
CEPA400 apresentou decréscimo de 10,98\% em relação ao controle (56 DAA). Com esses dados pode-se afirmar que o IC\% pode ser usado na relação fonte/dreno ao longo de um período de observações.

\subsection{CONCLUSÕES}

a) Após a tuberização, os reguladores vegetais nas concentrações utilizadas não afetaram a área foliar e a massa de matéria seca das folhas, mas aumentou a massa de matéria seca dos tubérculos de plantas tratadas com CCC $500 \mathrm{mg} \cdot \mathrm{L}^{-1}$ e NAA $15 \mathrm{mg} . \mathrm{L}^{-1}$ (42 DAA).

b) O CEPA na concentração de $400 \mathrm{mg} \cdot \mathrm{L}^{-1}$, promoveu incremento na massa de matéria seca das hastes, diminuindo a massa de matéria seca dos tubérculos no final do ciclo da cultura (56 DAA).

c) As aplicações com CCC na concentração de 500 mg. $\mathrm{L}^{-1}$ e NAA 15 mg. $\mathrm{L}^{-1}$, promoveram aumento na massa de matéria seca dos tubérculos (42 DAA).

d) Os parâmetros de análise de crescimento (taxa de crescimento foliar relativo, taxa de crescimento relativo, taxa de produção de matéria seca e taxa assimilatória líquida), mostraram-se eficientes na interpretação dos efeitos causados pela aplicação dos reguladores vegetais. 


\section{EFEITOS DE REGULADORES VEGETAIS NO DESENVOLVIMENTO E PRODUTIVIDADE DA CULTURA DE BATATA (Solanum tuberosum L. cv Achat) APÓS A TUBERIZAÇÃO ${ }^{1}$ \\ S. TAVARES ${ }^{2}$; A. A. LUCCHESI, Depto. de Ciências Biológicas - ESALQ/USP - CEP: 13480-900 - Piracicaba, SP.}

\subsection{RESUMO}

Com o objetivo de estudar os efeitos de reguladores vegetais no desenvolvimento e na produção final na cultura da batata (Solamum tuberosum L.) cultivar Achat, instalouse experimento em condições de campo, no período entre as estações outono-inverno.

As aplicações dos reguladores vegetais via foliar, foi efetuada aos 45 dias após o plantio. Foram aplicados: ácido giberélico $\left(\mathrm{GA}_{3}\right)$ à $15 \mathrm{mg} . \mathrm{L}^{-1}$, ácido naftalenacético (NAA) à $15 \mathrm{mg} . \mathrm{L}^{-1}$, ácido (2-cloroetil) fosfônico (CEPA) à 200 e $400 \mathrm{mg} . \mathrm{L}^{-1}$, cloreto de mepiquat (PIX) à 25 e $50 \mathrm{mg} . \mathrm{L}^{-1}$, cloreto de (2-cloroetil) trimetilamônio (CCC) à $250 \mathrm{e}$ $500 \mathrm{mg} . \mathrm{L}^{-1}$ além do controle.

O delineamento experimental adotado foi blocos casualizados, com nove tratamentos com três repetições. Foram determinados: área foliar, altura das plantas, comprimento dos estolões, número de hastes e número de entrenós. Também avaliou-se o número de tubérculos, número de tubérculos menores que $28 \mathrm{~mm}$ e a produção final sendo classificada em produção comercial e descarte.

\footnotetext{
${ }^{1}$ Parte da dissertação apresentada a ESALQ/USP em Fisiologia e Bioquímica de Plantas.

${ }^{2}$ Bolsista da CAPES, pós-graduando em Fisiologia e Bioquímica de Plantas - ESALQ/USP.
} 
Os reguladores vegetais aplicados não afetaram a área foliar, o número de hastes, o número de entrenós, o número de tubérculos, porém aumentaram a produção de tubérculos sementes. Os resultados obtidos revelaram que $\mathrm{GA}_{3}$ aumentou a altura das plantas, indicando um potencial de uso em culturas onde o tamanho das hastes tem importância econômica. Os reguladores vegetais aplicados após a tuberização, não afetaram a produção final de tubérculos do tipo I, II e III.

Palavras chaves: Solanum tuberosum, reguladores vegetais, produtividade

\section{EFFECTS OF GROWTH REGULATORS ON DEVELOPMENT AND PRODUCTIVITY OF POTATO CROP (Solanum tuberosum L. cv Achat) AFTER TUBERIZATION}

\subsection{SUMMARY}

This research deals with the effects of growth regulators on the development and productivity on the potato crop (Solanum tuberosum L. cv. Achat). Potato plants at 45 days after planting were sprayed with gibberellic acid $\left(\mathrm{GA}_{3}\right) 15 \mathrm{mg} . \mathrm{L}^{-1}$, naphthalene acetic acid (NAA) $15 \mathrm{mg} . \mathrm{L}^{-1}$, (2-chloroethyl) phosphonic acid (CEPA) 200 and $400 \mathrm{mg} . \mathrm{L}^{-1}$, mepiquat chloride (PIX) 25 and $50 \mathrm{mg} . \mathrm{L}^{-1}$, (2-chloroethyl) trimethyl ammonium chloride (CCC) 250 and $500 \mathrm{mg} . \mathrm{L}^{-1}$ and control in the autumm-spring cycle.

The experiment were distributed in 3 randomized blocks for each treatment. The main parameters analized were leaf area, plant heigth, stolons length, stems and internodes number. Tubers per plant and tubers less than $28 \mathrm{~mm}$ were assessed.

The growth regulators sprayed didn't affect the leaf area, stem and internodes number, but increased the yield of size seed tubers. Growth regulators applied after tuberization, affected type I $\left(\mathrm{GA}_{3} 15 \mathrm{mg} . \mathrm{L}^{-1}\right.$, PIX 25 and $50 \mathrm{mg} . \mathrm{L}^{-1}$, and CCC 250 and 
$500 \mathrm{mg} \cdot \mathrm{L}^{-1}$ ), type II (NAA $15 \mathrm{mg} . \mathrm{L}^{-1}$ and CCC $500 \mathrm{mg} \cdot \mathrm{L}^{-1}$ ) and type III with CCC 250 mg. $L^{-1}$.

Key words: Solanum tuberosum, growth regulators, productivity.

\subsection{INTRODUÇÃO}

O emprego"de reguladores vegetais na cultura de batata é de grande interesse, por se tratar de cultura que emprega técnicas bastante avançadas. Poucos trabalhos são relacionados na literatura, com relação ao emprego de reguladores vegetais e o desenvolvimento dessa cultura, após completa tuberização.

Sachs (1965) através de vários estudos sobre crescimento de caules, sugeriu que o meristema subapical é a principal faixa de tecido para a ação de giberelinas. Aplicações com $\mathrm{GA}_{3}$ nas concentrações de 50 e 100 g.ha $^{-1}$ no início da tuberização, promoveram alongamento de hastes e estolões (Bodlaender \& Waart, 1989).

Shadeque \& Pandita (1982), relataram que altas concentrações de chlormequat aplicadas tardiamente diminuiram a altura das plantas. A aplicação de chlormequat (500 $\left.\mathrm{mg} . \mathrm{L}^{-1}\right)$ aos 50 dias após o plantio, aumentou a produção e o número de tubérculos maiores.

Soares et al. (1982) conseguiram aumento médio de $12 \%$ na produção, além do aumento do número de tubérculos por planta nos cultivares Bintje e Baronesa, com aplicação de cloreto de mepiquat (0 a 150 g i.a.ha $\left.{ }^{-1}\right)$ aos 30-40 dias da germinação. Aumento de 19,1\% foi conseguido por Cruz (1982), com cloreto de mepiquat aplicado no cultivar Omega na concentração entre 50 e 75 g.ha $^{-1}$.

Meltzer (1992) observou aumento do número de tubérculos para cultivares tardios com aplicação de ácido (2-cloroetil)fosfônico $\left(150 \mathrm{ml}^{-h^{-1}}\right)$. Koller \& Hiller 
(1988) notaram aumento do número de tubérculos fora de padrão comercial (descarte), com aplicação de ácido (2-cloroetil)fosfônico (183 g i.a.ha ${ }^{-1}$ ).

Sekhon \& Singh (1985) não observaram redução na altura de plantas tratadas com CCC aos 35 dias após o plantio, nas concentrações de 300, 600 ou $900 \mathrm{ml}^{-h^{-1}}$, porém a altura foi reduzida quando a menor concentração (300 ml.ha $\left.{ }^{-1}\right)$ de CCC foi aplicada aos 21 dias após o plantio.

Khan et al. (1995) relacionaram o efeito de promotores de crescimento em relação à tratamentos com imersão de tubérculos e aplicação foliar. Verificaram que a aplicação foliar proporcionou maior produção final quando comparada com o controle. Ahmed \& Tahir (1995) estudaram a influência do ácido giberélico (100 mg. $\left.\mathrm{L}^{-1}\right)$, ácido naftalenacético $\left(100 \mathrm{mg} \cdot \mathrm{L}^{-1}\right)$, benziladenina $\left(20 \mathrm{mg} \cdot \mathrm{L}^{-1}\right)$ e suas combinações em pulverizações. Sugeriram que o número de tubérculos por planta é fator determinante para o tamanho médio de tubérculos de batata.

Islam \& Alam (1989) verificaram que plantas tratadas com CCC aumentaram o número de tubérculos por planta. Porém Mattar \& Abdul (1988), observaram que não houve efeito significativo para o número de tubérculos por planta quando aplicaram ácido giberélico $\left(25,50\right.$ ou $\left.100 \mathrm{mg} . \mathrm{L}^{-1}\right)$ e chlormequat $\left(250,500\right.$ e $\left.1000 \mathrm{mg} . \mathrm{L}^{-1}\right)$.

O objetivo do trabalho foi avaliar possiveis correlações entre área foliar $\left(\mathrm{dm}^{2}\right)$, altura $(\mathrm{cm})$, comprimento dos estolões $(\mathrm{cm})$, número de hastes, entrenós e tubérculos com a produtividade da cultura.

\subsection{MATERIAL E MÉTODOS}

O experimento foi conduzido em condições de campo com 580 metros de altitude, localizado no Sítio Roseira, municipio de Sumaré, Estado de São Paulo. O plantio foi realizado no final de outono, em Latossolo vermelho amarelo fase arenosa, utilizando-se tubérculos do tipo II (Brasil, 1988), cultivar Achat. Aos 45 dias do plantio, efetuaram-se as aplicações com os seguintes reguladores vegetais: ácido giberélico $\left(\mathrm{GA}_{3}\right)$ à $15 \mathrm{mg} . \mathrm{L}^{-1}$, ácido (2-cloroetil) fosfônico (CEPA) à $200 \mathrm{e} 400 \mathrm{mg} . \mathrm{L}^{-1}$, cloreto de 
mepiquat (PIX) à 25 e $50 \mathrm{mg} \cdot \mathrm{L}^{-1}$, cloreto (2-cloroetil) trimetilamônio (CCC) à 250 e 500 $\mathrm{mg} . \mathrm{L}^{-1}$, ácido naftalenacético (NAA) à $15 \mathrm{mg} . \mathrm{L}^{-1}$, além do controle.

Os parâmetros avaliados referem-se a área foliar, altura das plantas $(\mathrm{cm})$, número de hastes, número de entrenós por haste, comprimento dos estolões $(\mathrm{cm})$ aos 28 dias após a aplicação. Também avaliou-se o número de tubérculos por planta, número de tubérculos menores que $28 \mathrm{~mm}$ aos 42 dias após a aplicação. A produção total, foi classificada em comercial, tipos de sementes e descarte, em toneladas por hectare.

Foi utilizado o delineamento experimental blocos casualizados com três repetições, mantendo-se 64 plantas por parcela. Cada parcela constituiu-se de quatro linhas de plantas com $5,0 \mathrm{~m}$ de comprimento $\left(16,0 \mathrm{~m}^{2}\right)$, isoladas por três linhas de bordadura.

Realizou-se a comparação de médias pelo teste Tukey, ao nível de $5 \%$ de probabilidade para a diferença mínima significativa.

\subsection{RESULTADOS E DISCUSSÃO}

Pela TABELA 1, verificou-se aos 28 dias após a aplicação que a área foliar das plantas de batata não foi afetada significativamente pelos reguladores vegetais. Isso pode estar relacionado com a completa expansão foliar na época em que os reguladores vegetais foram aplicados.

Notou-se que a aplicação de $\mathrm{GA}_{3}\left(15 \mathrm{mg} \cdot \mathrm{L}^{-1}\right)$, aumentou significativamente a altura das plantas com relação ao controle e também às aplicações com CEPA e CCC (500 mg. $\mathrm{L}^{-1}$ ). De acordo com Sachs (1965), o meristema subapical é a principal faixa de tecido para a ação de giberelina. Bodlaender et al. (1989) também verifícaram alongamento de hastes com aplicação de $\mathrm{GA}_{3}$ nas concentrações entre 50 e 100 g.ha $^{-1}$, no início da tuberização.

As aplicações com CEPA diminuiram a altura das plantas, enquanto que PIX (25 mg. $\left.\mathrm{L}^{-1}\right)$, CCC (250 mg. $\left.\mathrm{L}^{-1}\right)$ e NAA $\left(15 \mathrm{mg} \cdot \mathrm{L}^{-1}\right)$ aumentaram significativamente. A aplicação de CCC (250 mg. $\left.\mathrm{L}^{-1}\right)$ aos 45 dias após o plantio promoveu aumento da altura; no entanto, Sekhon \& Singh (1985) obtiveram redução da altura das plantas quando 
aplicaram $300 \mathrm{ml}^{-h^{-1}}$ de CCC aos 21 dias após o plantio. Esses dados sugerem que a época de aplicação é fator determinante nos resultados obtidos.

TABELA 1 - Efeitos de reguladores vegetais na área foliar $\left(\mathrm{dm}^{2}\right)$, altura $(\mathrm{cm})$, comprimento dos estolões $(\mathrm{cm})$, número de hastes e número de entrenós na cultura da batata cultivar Achat, aos 28 dias após a aplicação. Valores de F, Tukey (5\%) e coeficiente de variação.

\begin{tabular}{|c|c|c|c|c|c|}
\hline \multirow[b]{2}{*}{ tratamentos } & \multicolumn{5}{|c|}{ 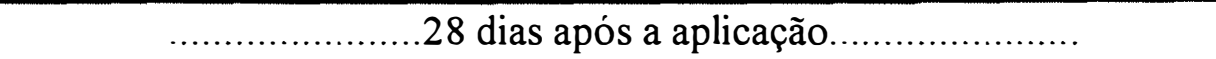 } \\
\hline & $\begin{array}{l}\text { Área foliar } \\
\left(\mathrm{dm}^{2}\right)\end{array}$ & $\begin{array}{c}\text { Altura } \\
(\mathrm{cm})\end{array}$ & $\begin{array}{l}\text { Estolões } \\
(\mathrm{cm})\end{array}$ & $\begin{array}{c}\text { número } \\
\text { hastes }\end{array}$ & $\begin{array}{l}\text { número } \\
\text { Entrenós }\end{array}$ \\
\hline CONTROLE & 36,33 & $0,48 \mathrm{bcd}$ & $6,17 \mathrm{ab}$ & 3,57 & 13,0 \\
\hline $\mathrm{GA}_{3}$ & 47,16 & $0,66 \mathrm{a}$ & $5,67 b$ & 3,72 & 15,3 \\
\hline CEPA 200 & 38,73 & $0,42 \mathrm{~cd}$ & $8,36 \mathrm{ab}$ & 3,31 & 12,3 \\
\hline CEPA 400 & 34,93 & $0,39 \mathrm{~d}$ & $6,90 \mathrm{ab}$ & 3,19 & 13,3 \\
\hline PIX 25 & 63,70 & $0,57 \mathrm{ab}$ & $5,96 \mathrm{ab}$ & 3,31 & 14,0 \\
\hline PI X 50 & 58,93 & $0,55 \mathrm{abc}$ & $7,35 \mathrm{ab}$ & 3,40 & 14,3 \\
\hline CCC 250 & 63,83 & $0,59 a b$ & $7,48 \mathrm{ab}$ & 2,68 & 14,6 \\
\hline CCC 500 & 55,66 & $0,52 \mathrm{bcd}$ & $6,14 \mathrm{ab}$ & 3,26 & 15,6 \\
\hline NAA & 66,16 & $0,57 \mathrm{ab}$ & $9,30 \mathrm{a}$ & 3,40 & 11,6 \\
\hline F (trat.) & $2,33 \mathrm{~ns}$ & $10,25 *$ & $2,85 *$ & $0,42 \mathrm{n} \mathrm{s}$ & $1,78 \mathrm{n} \mathrm{s}$ \\
\hline $\mathrm{CV}(\%)$ & 27,68 & 8,79 & 17,67 & 23,16 & 12,61 \\
\hline
\end{tabular}

Os reguladores vegetais aplicados não afetaram o comprimento médio dos estolões em relação ao controle aos 28 dias após a aplicação. Somente a aplicação com $\mathrm{GA}_{3}\left(15 \mathrm{mg} . \mathrm{L}^{-1}\right)$ foi significativamente menor em relação a NAA (15 mg. $\left.\mathrm{L}^{-1}\right)$, sugerindo desequilíbrio hormonal na relação giberelina/auxina endógena nos estolões.

Com relação ao número de hastes, não houve atuação efetiva dos reguladores vegetais na dominância apical, aplicados aos 45 dias após o plantio, sendo que o número de entrenós também não foi afetado.

Observa-se (TABELA 2), que os reguladores vegetais aplicados aos 45 dias após o plantio não afetaram o número de tubérculos por planta, indicando que nesta época, os tubérculos já estavam definidos ou que as concentrações aplicadas foram insuficientes para alterar esse parâmetro. Resultados semelhantes foram obtidos por Mattar \& Abdul 
(1988) quando aplicaram $\mathrm{GA}_{3}\left(25,50\right.$ e $\left.100 \mathrm{mg} \cdot \mathrm{L}^{-1}\right)$ e $\mathrm{CCC}\left(250,500\right.$ e $\left.1000 \mathrm{mg} \cdot \mathrm{L}^{-1}\right)$, entretanto Islam \& Alam (1989), conseguiram maior número de tubérculos por planta.

TABELA 2 - Efeitos de reguladores vegetais na cultura da batata cultivar Achat, no número de tubérculos, tubérculos menores $(28,0 \mathrm{~mm})$ aos 42 dias após a aplicação e produção total, comercial e descarte (ton.ha ${ }^{-1}$ ). Valores de F, Tukey (5\%) e coeficiente de variação.

\begin{tabular}{|c|c|c|c|c|c|}
\hline \multirow[b]{2}{*}{ tratamentos } & \multicolumn{2}{|c|}{42 dias após a aplicação } & \multicolumn{3}{|c|}{ Produção } \\
\hline & $\begin{array}{l}\text { tubérculos } \\
\text { por planta }\end{array}$ & $\begin{array}{l}\text { tubérculos } \\
(<28,0 \mathrm{~mm})\end{array}$ & $\begin{array}{c}\text { Total } \\
\left(\text { ton. }^{-1} a^{-1}\right)\end{array}$ & $\begin{array}{c}\text { Comercial } \\
\left(\text { ton.ha }{ }^{-1}\right)\end{array}$ & $\begin{array}{l}\text { Descarte } \\
\left(\text { ton. }^{-1}\right)^{-1} \text { ) }\end{array}$ \\
\hline CONTROLE & 10,33 & $3,0 \mathrm{~b}$ & $51,2 \mathrm{ab}$ & $47,9 \mathrm{ab}$ & 3,2 \\
\hline $\mathrm{GA}_{3}$ & 13,66 & $4,0 \mathrm{~b}$ & $50,0 \mathrm{ab}$ & $46,6 \mathrm{ab}$ & 3,4 \\
\hline CEPA 200 & 15,66 & $6,3 \mathrm{ab}$ & $50,0 \mathrm{ab}$ & $46,4 \mathrm{ab}$ & 3,6 \\
\hline CEPA 400 & 22,33 & $12,3 \mathrm{a}$ & $40,6 \mathrm{~b}$ & $36,1 \mathrm{~b}$ & 4,5 \\
\hline PIX 25 & 12,66 & $5,3 \mathrm{ab}$ & $60,7 \mathrm{a}$ & $57,4 \mathrm{a}$ & 3,2 \\
\hline PIX 50 & 13,00 & $4,6 \mathrm{~b}$ & 54,6 a & $52,3 \mathrm{a}$ & 2,3 \\
\hline CCC 250 & 11,33 & $4,0 \mathrm{~b}$ & $60,8 \mathrm{a}$ & $57,4 \mathrm{a}$ & 3,3 \\
\hline CCC 500 & 10,66 & $3,3 \mathrm{~b}$ & $55,7 \mathrm{a}$ & $52,3 \mathrm{a}$ & 3,4 \\
\hline NAA & 13,66 & $3,6 \mathrm{~b}$ & $50,2 \mathrm{ab}$ & $47,8 \mathrm{ab}$ & 2,3 \\
\hline$F$ (trat.) & $2,20 \mathrm{~ns}$ & $3,53 *$ & $6,42 *$ & $7,25 *$ & $0,77 \mathrm{~ns}$ \\
\hline $\mathrm{CV}(\%)$ & 31,02 & 51,02 & 8,08 & 8,55 & 40,63 \\
\hline
\end{tabular}

As aplicações com CEPA embora não sejam significativas, mostraram tendência de aumento do número de tubérculos. O mesmo foi observado por Meltzer (1992) em cultivares tardios, com aplicação com CEPA (150 ml.ha $\left.{ }^{-1}\right)$. Observando -se a aplicação com CEPA (400 mg. $\mathrm{L}^{-1}$ ), houve aumento do número de tubérculos com tamanho menor que $28 \mathrm{~mm}$ (descarte). Isto pode estar relacionado com a senescência precoce provocada pelo uso do ácido (2-cloroetil) fosfônico.

A aplicação dos reguladores vegetais, afetou a produção total e comercial de tubérculos. Os retardadores de crescimento (PIX e CCC) nas menores concentrações aplicadas, tenderam a aumento de $18 \%$ em relação ao controle. Aumentos na produção também foram verificados em outros trabalhos realizados (Soares et al., 1982; Cruz, 1982; Shadeque \& Pandita, 1982 e Sekhon \& Singh, 1985). Não foi observado efeito da 
aplicação dos reguladores vegetais em relação ao descarte de tubérculos, indicando que o número de tubérculos menores observados aos 42 dias após a aplicação com CEPA (400 mg. $L^{-1}$ ), continuaram crescendo numa taxa de crescimento mais lenta. Marchner et al. (1984) constataram correlação positiva entre taxa de crescimento e níveis de auxina.

TABELA 3 - Efeito de reguladores vegetais quanto ao tipo de tubérculo-semente, na cultura da batata cultivar Achat. Valores de F (5\%), teste de Tukey e coeficiente de variação.

\begin{tabular}{lcccc}
\hline & \multicolumn{4}{c}{ Tipos de tubérculos-sementes (ton.ha $\left.{ }^{-1}\right)$} \\
\hline tratamentos & I & II & III & IV \\
\hline CONTROLE & $7,43 \mathrm{~d}$ & $14,92 \mathrm{~b}$ & $25,60 \mathrm{bc}$ & 3,28 \\
GA $_{3}$ & $11,38 \mathrm{ab}$ & $9,33 \mathrm{c}$ & $25,90 \mathrm{~b}$ & 3,40 \\
CEPA 200 & $8,26 \mathrm{~cd}$ & $9,93 \mathrm{c}$ & $28,18 \mathrm{ab}$ & 3,63 \\
CEPA 400 & $7,39 \mathrm{~d}$ & $9,23 \mathrm{c}$ & $19,39 \mathrm{~d}$ & 4,58 \\
PIX 25 & $12,09 \mathrm{ab}$ & $18,14 \mathrm{ab}$ & $27,18 \mathrm{ab}$ & 3,24 \\
PIX 50 & $10,92 \mathrm{ab}$ & $14,58 \mathrm{~b}$ & $26,72 \mathrm{~b}$ & 2,34 \\
CCC 250 & $10,22 \mathrm{abc}$ & $14,35 \mathrm{~b}$ & $32,79 \mathrm{a}$ & 3,37 \\
CCC 500 & $12,46 \mathrm{a}$ & $19,93 \mathrm{a}$ & $19,93 \mathrm{~cd}$ & 3,40 \\
NAA & $9,04 \mathrm{bcd}$ & $21,98 \mathrm{a}$ & $16,90 \mathrm{~d}$ & 2,30 \\
\hline F (trat.) & $14,87^{*}$ & $33,08 *$ & $19,21 *$ & $0,77 \mathrm{n} \mathrm{s}$ \\
CV (\%) & 8,84 & 9,54 & 8,02 & 40,63 \\
\hline
\end{tabular}

ns não significativo

${ }^{*}$ significativo ao nivel de $5 \%$ de probabilidade

A classificação da produção quanto ao tipo de tubérculo semente, indicou a ação dos reguladores vegetais aplicados após a tuberização (TABELA 3). A aplicação de $\mathrm{GA}_{3}$ $15 \mathrm{mg} . \mathrm{L}^{-1}$, aumentou a produção de tubérculos tipo I e diminuiu a quantidade de tubérculos do tipo II. O tratamento com NAA $15 \mathrm{mg} . \mathrm{L}^{-1}$, produziu mais tubérculos do tipo II, quando comparado ao controle. Os tratamentos com PIX (25 e $50 \mathrm{mg} . \mathrm{L}^{-1}$ ), produziram mais tubérculos do tipo I, em relação ao controle. Os resultados obtidos com CEPA (200 e $400 \mathrm{mg} \cdot \mathrm{L}^{-1}$ ), não se mostraram promissores. As maiores alterações positivas, foram obtidas com os tratamentos CCC: sendo que na concentração de 250 mg. $\mathrm{L}^{-1}$, ocorreu aumento na produção de tubérculos do tipo I e III e na concentração de $500 \mathrm{mg} . \mathrm{L}^{-1}$, o aumento verificado foi em tubérculos do tipo I e II. 
Uma hipótese que explicaria esse aumento de produção, seria a presença de receptores de membranas que codificariam sinais (RNAm), que ao serem transmitidos ao núcleo, produziria maior quantidade e/ou atividade de enzimas responsáveis pela síntese de sacarose (sacarose fosfato sintetase), inibindo dessa maneira, o armazenamento de carboidratos nas folhas. Consequentemente, essa sacarose seria enviada para as regiões de dreno (tubérculos).

\subsection{CONCLUSÕES}

a) Os reguladores vegetais aplicados em baixas concentrações, aos 45 dias após o plantio, não afetaram a área foliar, comprimento dos estolões, número de hastes e entrenós por planta, mas aumentou a produção de tubérculos-sementes (tipos).

b) Os tratamentos $\mathrm{GA}_{3}\left(15 \mathrm{mgL}^{-1}\right)$, PIX (25 e $\left.50 \mathrm{mg} \cdot \mathrm{L}^{-1}\right)$ e CCC $\left(250\right.$ e $\left.500 \mathrm{mg} \cdot \mathrm{L}^{-1}\right)$, aumentaram a produção de tubérculos-sementes do tipo I. NAA (15 mg. $\left.\mathrm{L}^{-1}\right)$ e CCC (500 $\left.\mathrm{mg} \cdot \mathrm{L}^{-1}\right)$, aumentaram a proporção de tipo II, enquanto que a concentração de CCC 250 $\mathrm{mg} . \mathrm{L}^{-1}$, aumentou a quantidade de tubérculos do tipo III. 
5 EFEITOS DA APLICAÇÃO DE REGULADORES VEGETAIS NO TEOR DE CARBOIDRATOS SOLÚVEIS TOTAIS E PROdUÇÃO FINAL DE TUBÉRCULOS DE BATATA (Solanum tuberosum L. cv Achat), APÓS A TUBERIZAÇÃO ${ }^{1}$

S. TAVARES ${ }^{2}$; A. A. LUCCHESI,

Depto de Ciências Biológicas - ESALQ/USP - CEP: 13418-900 - Piracicaba, SP.

\subsection{RESUMO}

Com a finalidade de detectar possiveis efeitos com a utilização de reguladores vegetais aplicados via foliar em plantas de batata (Solamum tuberosum L. cv Achat), analisou-se o teor de carboidratos totais solúveis em folhas e tubérculos a cada intervalo de 14 dias. Foi obtido também a produção final de tubérculos e sua classificação quanto ao tipo de tubérculo-semente. Foram aplicados: ácido giberélico $\left(\mathrm{GA}_{3}\right.$ a $\left.15 \mathrm{mg} \cdot \mathrm{L}^{-1}\right)$, ácido naftalenacético (NAA a $15 \mathrm{mg} \cdot \mathrm{L}^{-1}$ ), ácido (2-cloroetil)fosfônico (CEPA a 200 e 400 $\mathrm{mg} . \mathrm{L}^{-1}$ ), cloreto de mepiquat (PIX a 25 e $50 \mathrm{mg} . \mathrm{L}^{-1}$ ), cloreto de (2-cloroetil) trimetilamônio (CCC a 250 e $500 \mathrm{mg} \cdot \mathrm{L}^{-1}$ ), além do controle. Os resultados mostraram que os reguladores vegetais aplicados, atuaram à nível enzimático, promovendo alterações no conteúdo de carboidratos solúveis totais encontrados em folhas e tubérculos. Os retardadores de crescimento (PIX e CCC), mostraram que podem ser utilizados após a tuberização, alterando positivamente a produção de tubérculos sementes.

\footnotetext{
${ }^{1}$ Parte da dissertação apresentada a ESALQ/USP em Fisiologia e Bioquímica de Plantas.

${ }^{2}$ Bolsista da CAPES, pós-graduando em Fisiologia e Bioquímica de Plantas - ESALQ/USP.
} 
Nas condições de outono-inverno, os reguladores vegetais aplicados em baixas concentrações podem aumentaram a produção final de tubérculos sementes. $\mathrm{GA}_{3}$ (15mg.L $\left.\mathrm{L}^{-1}\right)$, PIX (25 e $\left.50 \mathrm{mg} . \mathrm{L}^{-1}\right)$ e CCC (250 e $\left.500 \mathrm{mg} \cdot \mathrm{L}^{-1}\right)$, aumentaram a produção de tubérculos do tipo I, enquanto que NAA (15 mg. $\left.\mathrm{L}^{-1}\right)$ e CCC $500 \mathrm{mg} . \mathrm{L}^{-1}$, aumentou a produção de tubérculos do tip II. O tratamento com CCC $250 \mathrm{mg} \cdot \mathrm{L}^{-1}$, proporcionou aumento de produção nos tubérculos tipo III.

Palavras chaves: Solanum tuberosum, carboidratos, tubérculos, reguladores vegetais.

\section{EFFECTS OF SOME GROWTH REGULATORS SPRAYS ON THE CARBOHYDRATE COMPOSITION AND YIELD OF TUBERS OF POTATO CROP (Solanum tuberosum L. cv Achat), AFTER TUBERIZATION}

\subsection{SUMMARY}

The objective of this work was to determine the effects of growth regulators sprays on carbohydrate composition in the leaves and tubers, at 14 day intervals, total yield and seed tubers was determined too.

It was applied: gibberellic acid $\left(\mathrm{GA}_{3}\right.$ at $\left.15 \mathrm{mg} \cdot \mathrm{L}^{-1}\right)$, naphthalenacetic acid (NAA at $\left.15 \mathrm{mg} . \mathrm{L}^{-1}\right)$, (2-chloroethyl) phosphonic acid (CEPA at 200 and $\left.400 \mathrm{mg} . \mathrm{L}^{-1}\right)$, mepiquat chloride (PIX at 25 and $50 \mathrm{mg} \cdot \mathrm{L}^{-1}$ ), (2-chloroethyl) trimethylammonium chloride (CCC at 250 and $\left.500 \mathrm{mg} \cdot \mathrm{L}^{-1}\right)$ and control.

The results showed that application of growth regulators, caused changes in assimilate partitioning. The growth retardants (PIX and CCC), may be used to control as desired the production. The autumn-spring cycle, low concentrations of growth regulators caused modifying on type I, II and III seed tubers yield. Higher production type I, was obtained with $\mathrm{GA}_{3}\left(15 \mathrm{mg} \cdot \mathrm{L}^{-1}\right)$, PIX (25 and $\left.50 \mathrm{mg} \cdot \mathrm{L}^{-1}\right)$ and CCC (250 and 
$\left.500 \mathrm{mg} \cdot \mathrm{L}^{-1}\right)$. NAA (15 mg. $\left.\mathrm{L}^{-1}\right)$ and CCC $500 \mathrm{mg} \cdot \mathrm{L}^{-1}$, increased type II and CCC 250 mg. $L^{-1}$, type III.

Key words: Solamum tuberosum, carbohydrate, seed tubers, growth regulators.

\subsection{INTRODUÇÃO}

Sharma et al. (1998) verificaram em plantas tratadas com CCC, que os açúcares redutores formados eram eficientemente reconvertidos para sacarose através da enzima sacarose fosfato sintetase, a eficiência no desenvolvimento dos tubérculos em converter sacarose marcada em amido, foi 2,5 vezes maior que o controle. Verificaram que a maior concentração de carboidratos nos tubérculos ocorreu aos 60 dias após a semeadura. Islam \& Alam (1989) observaram aumento no teor de açúcares totais com aplicação foliar de NAA em plantas de batata. Segundo Li (1985), o teor de açúcares em batata crua, varia em torno de $1,3 \%$.

Nickell (1994) mencionou que o efeito do retardador de crescimento ocorre na região subapical das brotações, onde a divisão e alongamento celular são inibidos.

Mauromicale (1982) verificou que o CCC e IAA, causaram rápido crescimento do tubérculo de batata, enquanto que $\mathrm{GA}_{3}$, retardou o crescimento. Marchner et al. (1984) acreditam que o teor de auxina endógena pode ser o fator responsável pelo controle da taxa de crescimento de tubérculos individuais.

Golovko \& Tabalenkova (1989) observaram que tecidos de tubérculos de plantas tratadas com $0,7 \%$ de CCC aos 25 dias da emergência, absorveram glicose marcada e converteram em amido mais rapidamente que o controle. Cruz (1982) verificou que o emprego de cloreto de mepiquat aumentou a produção comercial de batatas e não encontrou diferenças quanto ao teor (\%) de amido. 
Com a finalidade de detectar possiveis efeitos de reguladores vegetais aplicados via foliar em plantas de batata (Solanum tuberosum L., cv Achat), analisou-se o teor de carboidratos totais solúveis em folhas e tubérculos em intervalos de 14 dias. Analisou-se a produção final quanto à: produção total, comercial e tubérculos-sementes. A sacarose é o produto final da fotossintese e também o principal carboidrato translocado pelas plantas. A partição desse carboidrato solúvel, pode influenciar a produção final e o tamanho dos tubérculos.

\subsection{MATERIAL E MÉTODOS}

O trabalho foi conduzido no Sítio Roseira, no município de Sumaré, Estado de São Paulo, em Latossolo vermelho amarelo (fase arenosa), com altitude de $580 \mathrm{~m}$, durante o período outono-inverno. Utilizaram-se sementes do tipo II do cultivar Achat para o plantio.

Os reguladores vegetais foram aplicados em pulverização foliar aos 45 dias após o plantio, utilizando-se barras de pulverização sob pressão constante. Os reguladores vegetais aplicados foram: ácido giberélico $\left(\mathrm{GA}_{3}\right.$ a $\left.15 \mathrm{mg} . \mathrm{L}^{-1}\right)$, ácido naftalenacético (NAA a $15 \mathrm{mg} . \mathrm{L}^{-1}$ ), ácido (2-cloroetil) fosfônico (CEPA a 200 e $400 \mathrm{mg} . \mathrm{L}^{-1}$ ), cloreto de mepiquat (PIX a 25 e $50 \mathrm{mg} \cdot \mathrm{L}^{-1}$ ), cloreto de (2-cloroetil) trimetilamônio (CCC a 250 e $\left.500 \mathrm{mg} . \mathrm{L}^{-1}\right)$, além do controle.

$\mathrm{O}$ teor de carboidratos solúveis totais foi determinado por colorimetria (Klett Summerson, mod. 800-3), utilizando-se o método Fenol Sulfúrico (Dubois et al., 1956). As amostras de folhas e tubérculos eram coletadas a intervalos de 14 dias.

$\mathrm{Na}$ colheita, foram determinados a produção total, comercial e a classificação dos tubérculos quanto ao tipo de sementes, segundo as Normas Gerais para Certificação de batata-semente (Brasil, 1988).

\subsection{RESULTADOS E DISCUSSÃO}


Nota-se pela TABELA 1, que os reguladores vegetais aplicados não apresentaram efeitos significativos no teor de carboidratos solúveis totais (CST), em folhas de batata aos 14 e 28 dias após a aplicação (DAA). O maior teor de CST verificado nas folhas aos 42 DAA, com os tratamentos $\mathrm{GA}_{3}\left(15 \mathrm{mg} . \mathrm{L}^{-1}\right)$ e $\mathrm{CCC}\left(500 \mathrm{mg} . \mathrm{L}^{-1}\right)$, podem indicar segundo Mauromicale (1982), retardamento no crescimento dos tubérculos. Sharma et al. (1998) porém, acreditam que esse acúmulo de CST nas folhas, é devido à maior atividade da enzima sacarose fosfato sintetase.

TABELA 1 - Efeito de reguladores vegetais no teor de carboidratos solúveis totais (mg.g $\mathrm{g}^{-1}$ ), em folhas de batata (Solanum tuberosum L. cv Achat), aos 14, 28, 42 e 56 dias após a aplicação (DAA). Valores de F (trat.), teste de Tukey e coeficiente de variação.

\begin{tabular}{lcccc}
\hline & \multicolumn{5}{c}{ Carboidratos solúveis totais em folhas $\left(\mathrm{mg} \cdot \mathrm{g}^{-1}\right)$} \\
\hline tratamentos & 14 DAA & $28 \mathrm{DAA}$ & $42 \mathrm{DAA}$ & $56 \mathrm{DAA}$ \\
\hline CONTROLE & 4,42 & 6,59 & $2,38 \mathrm{cde}$ & 0,89 \\
GA $_{3}$ & 3,52 & 7,04 & $4,46 \mathrm{ab}$ & 0,73 \\
CEPA 200 & 3,80 & 6,21 & $2,52 \mathrm{bcde}$ & 0,79 \\
CEPA 400 & 5,01 & 6,02 & $0,74 \mathrm{e}$ & 0,99 \\
PIX 25 & 5,52 & 6,55 & $0,74 \mathrm{e}$ & 0,99 \\
PIX 50 & 3,86 & 6,58 & $0,89 \mathrm{de}$ & 0,83 \\
CCC 250 & 4,38 & 7,19 & $2,82 \mathrm{bcd}$ & 0,79 \\
CCC 500 & 3,88 & 6,96 & $5,05 \mathrm{a}$ & 0,67 \\
NAA & 3,51 & 6,25 & $3,86 \mathrm{abc}$ & 0,99 \\
\hline F (trat.) & $1,64 \mathrm{n} \mathrm{s}$ & $0,45 \mathrm{n} \mathrm{s}$ & $17,27^{*}$ & $0,58 \mathrm{n} \mathrm{s}$ \\
CV (\%) & 22,05 & 15,56 & 25,88 & 31,54 \\
\hline
\end{tabular}

ns não significativo

* significativo ao nível de $5 \%$ de probabilidade

A TABELA 2, mostra os efeitos da aplicação dos reguladores vegetais no teor de carboidratos solúveis totais em tubérculos de batata. Aos 14 DAA, o tratamento com PIX (50 mg.L-1), aumentou significativamente o teor de carboidratos solúveis totais, em relação ao controle. Verifica-se também, uma tendência de elevados teores de CST com os tratamentos $\mathrm{GA}_{3}\left(15 \mathrm{mg} \cdot \mathrm{L}^{-1}\right)$, CEPA (200 e $400 \mathrm{mg} . \mathrm{L}^{-1}$ ), PIX $25 \mathrm{mg} . \mathrm{L}^{-1}$ e NAA 15 $\mathrm{mg} . \mathrm{L}^{-1}$, podendo indicar maior translocação de carboidratos para os tubérculos. Segundo Marchner et al. (1984), o teor de auxina endógena pode ser o fator responsável no controle da taxa de crescimento de tubérculos individuais. 
Aos 28 DAA, apesar de não ter ocorrido variações significativas entre os tratamentos efetuados, verifica-se uma tendência de maior concentração de carboidratos solúveis totais para os tratamentos $\mathrm{GA}_{3}\left(15 \mathrm{mg} . \mathrm{L}^{-1}\right)$, CEPA $200 \mathrm{mg} . \mathrm{L}^{-1}$, PIX (25 e 50 mg. $\mathrm{L}^{-1}$ ) e NAA $15 \mathrm{mg} . \mathrm{L}^{-1}$, em relação ao controle. $\mathrm{O}$ mesmo efeito é verificado aos 42 DAA, com CEPA $400 \mathrm{mg} . \mathrm{L}^{-1}$ e PIX (25 e $\left.50 \mathrm{mg} \cdot \mathrm{L}^{-1}\right)$.

TABELA 2 - Efeito de reguladores vegetais no teor de carboidratos solúveis totais (mg. $\left.\mathrm{g}^{-1}\right)$, em tubérculos de batata (Solanum tuberosum L., cv Achat), aos 14, 28, 42 e 56 dias após a aplicação. Valores de F (trat.), teste de Tukẹ e coeficiente de variação.

\begin{tabular}{lcccc}
\hline & \multicolumn{4}{c}{ Carboidratos solúveis totais em tubérculos $\left(\mathrm{mg}^{-\mathrm{g}^{-1}}\right)$} \\
\hline tratamentos & 14 & 28 & 42 & 56 \\
\hline CONTROLE & $0,65 \mathrm{~b}$ & 0,14 & $0,79 \mathrm{abc}$ & $0,67 \mathrm{a}$ \\
GA $_{3}$ & $1,28 \mathrm{ab}$ & 0,30 & $1,41 \mathrm{ab}$ & $0,22 \mathrm{c}$ \\
CEPA 200 & $1,10 \mathrm{ab}$ & 0,31 & $0,84 \mathrm{abc}$ & $0,47 \mathrm{abc}$ \\
CEPA 400 & $1,11 \mathrm{ab}$ & 0,10 & $0,27 \mathrm{c}$ & $0,46 \mathrm{abc}$ \\
PIX 25 & $1,31 \mathrm{ab}$ & 0,29 & $0,27 \mathrm{c}$ & $0,29 \mathrm{bc}$ \\
PIX 50 & $1,98 \mathrm{a}$ & 0,23 & $0,32 \mathrm{c}$ & $0,53 \mathrm{abc}$ \\
CCC 250 & $0,56 \mathrm{~b}$ & 0,17 & $0,70 \mathrm{bc}$ & $0,57 \mathrm{abc}$ \\
CCC 500 & $0,57 \mathrm{~b}$ & 0,20 & $1,65 \mathrm{a}$ & $0,63 \mathrm{ab}$ \\
NAA & $1,33 \mathrm{ab}$ & 0,31 & $0,77 \mathrm{abc}$ & $0,58 \mathrm{abc}$ \\
\hline F (trat.) & $6,86 *$ & $2,90 \mathrm{n} \mathrm{s}$ & $6,72 *$ & $4,17 *$ \\
CV (\%) & 27,38 & 34,82 & 41,61 & 25,86 \\
\hline
\end{tabular}

ns não significativo

* significativo ao nível de $\mathbf{5 \%}$ de probabilidade

Os menores teores de CST encontrados com a aplicação de CCC, podem indicar maior eficiência de conversão de sacarose em amido. Sharma et al. (1998) fizeram sete aplicações com CCC (12,5 mM), em intervalos de 5 dias, a partir dos 25 dias após a semeadura e verificaram eficiência de 2,5 vezes maior dos tubérculos em desenvolvimento na conversão de sacarose em amido em relação ao controle. No presente experimento, com uma única aplicação aos 45 dias após o plantio, esse aspecto não foi verificado em relação ao controle.

Niveis inferiores que $1 \mathrm{mg} . \mathrm{g}^{-1}$, foram encontrados em folhas de batata aos 42 DAA com CEPA 400 e PIX indicando provavelmente, menor taxa de síntese de sacarose. 
Aos 56 DAA, ocorreu uma diminuiução significativa no teor de CST dos tubérculos de plantas tratadas com GA 3 ( $\left.15 \mathrm{mg} . \mathrm{L}^{-1}\right)$ e PIX $\left(25 \mathrm{mg} . \mathrm{L}^{-1}\right)$, indicando o final de sua ação na planta.

Os maiores teores de CST encontrados nos tubérculos aos 14 DAA com os tratamentos $\mathrm{GA}_{3}, \mathrm{CEPA}$, PIX e NAA, podem indicar inibição da enzima responsável pela conversão de sacarose em amido ou aumento da atividade da sacarose fosfato sintetase na região de síntese. $\mathrm{O}$ aumento do teor de açúcares totais observado por Islam \& Alam (1989), com aplicação de NAA em plantas de batata, não foi verificado no presente trabalho.

Os dados (TABELA 3) mostraram que os reguladores vegetais nas concentrações aplicadas não afetaram a produção total e a comercial; houve porém tendência de decréscimo da produção total nas plantas tratadas com CEPA 400 e acréscimo para as plantas que receberam PIX e CCC.

Quanto ao tipo de tubérculo-semente, segundo as Normas Gerais para Certificação de Sementes (Brasil, 1988), verificou-se aumento de: 53\% para o tratamento $\mathrm{GA}_{3}\left(15 \mathrm{mg} . \mathrm{L}^{-1}\right), 62 \%$ para PIX (25 mg. $\left.\mathrm{L}^{-1}\right), 46 \%$ para PIX (50 mg. $\left.\mathrm{L}^{-1}\right), 37 \%$ para CCC (250 mg. $\left.\mathrm{L}^{-1}\right)$ e $67 \%$ para CCC (500 mg. $\left.\mathrm{L}^{-1}\right)$, na média de tubérculos do tipo I, quando comparados ao controle.

Para o tipo II de tubérculo-semente, o aumento observado foi de $33 \%$ para CCC (500 mg. $\left.\mathrm{L}^{-1}\right)$ e $47 \%$ para o tratamento com NAA $\left(15 \mathrm{mg} \cdot \mathrm{L}^{-1}\right)$. Foi verificado aumento de $28 \%$ em tubérculos do tipo III, somente com o tratamento CCC $250 \mathrm{mg} . \mathrm{L}^{-1}$. Marchner et al. (1984) acreditam que o teor de auxina endógena pode ser o fator responsável pelo controle da taxa de crescimento de tubérculos individuais. Isso pode ser notado quando se compara tubérculo-semente do tipo II entre o tratamento com NAA 15 mg. $\mathrm{L}^{-1}$ $(47,3 \%)$ e o controle. Provavelmente a relação adequada entre GANAA, quanto ao crescimento dos tubérculos, foi estabelecida com as menores concentrações de PIX e CCC aplicadas, uma vez que foi observado as maiores produções. Cruz (1982), encontrou resultados semelhantes para aplicações com PIX. 
Mauromicale (1982) notou rápido crescimento de tubérculos com aplicação de CCC e NAA, enquanto que plantas tratadas com $\mathrm{GA}_{3}$, tiveram seu crescimento retardado.

TABELA 3 - Efeito de reguladores vegetais na produtividade (ton.ha ${ }^{-1}$ ) total, comercial e classificação quanto ao tipo de tubérculo-semente, na cultura da batata cultivar Achat. Valores de $\mathrm{F}$ (5\%), teste de Tukey e coeficiente de variação.

\begin{tabular}{lcccccc}
\hline & Produtividade(ton.ha ${ }^{-1}$ ) & \multicolumn{5}{c}{ Tipos de tubérculo-semente } \\
\hline tratamentos & total & comercial & I & II & III & IV \\
\hline CONTROLE & $51,26 \mathrm{ab}$ & $47,98 \mathrm{ab}$ & $7,43 \mathrm{~d}$ & $14,92 \mathrm{~b}$ & $25,60 \mathrm{bc}$ & 3,28 \\
GA & $50,07 \mathrm{ab}$ & $46,67 \mathrm{ab}$ & $11,38 \mathrm{ab}$ & $9,33 \mathrm{c}$ & $25,90 \mathrm{~b}$ & 3,40 \\
CEPA 200 & $50,06 \mathrm{ab}$ & $46,42 \mathrm{ab}$ & $8,26 \mathrm{~cd}$ & $9,93 \mathrm{c}$ & $28,18 \mathrm{ab}$ & 3,63 \\
CEPA 400 & $40,64 \mathrm{~b}$ & $36,06 \mathrm{~b}$ & $7,39 \mathrm{~d}$ & $9,23 \mathrm{c}$ & $19,39 \mathrm{~d}$ & 4,58 \\
PIX 25 & $60,72 \mathrm{a}$ & $57,47 \mathrm{a}$ & $12,09 \mathrm{ab}$ & $18,14 \mathrm{ab}$ & $27,18 \mathrm{ab}$ & 3,24 \\
PIX 50 & $54,64 \mathrm{a}$ & $52,30 \mathrm{a}$ & $10,92 \mathrm{ab}$ & $14,58 \mathrm{~b}$ & $26,72 \mathrm{~b}$ & 2,34 \\
CCC 250 & $60,82 \mathrm{a}$ & $57,44 \mathrm{a}$ & $10,22 \mathrm{abc}$ & $14,35 \mathrm{~b}$ & $32,79 \mathrm{a}$ & 3,37 \\
CCC 500 & $55,77 \mathrm{a}$ & $52,37 \mathrm{a}$ & $12,46 \mathrm{a}$ & $19,93 \mathrm{a}$ & $19,93 \mathrm{~cd}$ & 3,40 \\
NAA & $50,19 \mathrm{ab}$ & $47,89 \mathrm{ab}$ & $9,04 \mathrm{bcd}$ & $21,98 \mathrm{a}$ & $16,90 \mathrm{~d}$ & 2,30 \\
\hline F (trat.) & $6,42 *$ & $7,25 *$ & $14,87 *$ & $33,08 *$ & $19,21 *$ & $0,77 \mathrm{n} \mathrm{s}$ \\
CV (\%) & 8,08 & 8,55 & 8,84 & 9,54 & 8,02 & 40,63 \\
\hline
\end{tabular}

ns não significativo

* significativo ao nível de $5 \%$ de probabilidade

No presente trabalho, $\mathrm{GA}_{3}$ diminuiu somente tubérculos do tipo II. Golovko \& Tabalenkova (1989) verificaram em plantas tratadas com CCC (70 mg. $\mathrm{L}^{-1}$ ), maior eficiência na conversão de glicose marcada em amido, quando comparadas ao controle.

A FIGURA 1, foi elaborada para mostrar os efeitos dos reguladores vegetais aplicados, quanto à distribuição dos tipos de tubérculos-semente em relação ao controle. A aplicação de $\mathrm{GA}_{3}$ aumentou a produção de tubérculos tipo I e diminuiu o tipo II (A), enquanto que NAA aumentou a produção de tubérculos do tipo II e diminuiu a produção de tubérculos do tipo III (B).

O tratamento com PIX (25 e $50 \mathrm{mg} . \mathrm{L}^{-1}$ ), aumentou somente a quantidade de tubérculos do tipo I (C). O retardador de crescimento CCC (250 mg. $\left.\mathrm{L}^{-1}\right)$, aumentou a produção de tubérculos do tipo I e III e na concentração de $500 \mathrm{mg} . \mathrm{L}^{-1}$, provocou aumento dos tipos I e II (D). A aplicação com CEPA (200 mg. $\left.\mathrm{L}^{-1}\right)$, diminuiu a 
quantidade de tubérculos do tipo II e com $400 \mathrm{mg} . \mathrm{L}^{-1}$, diminuiu também a quantidade do tipo III (E).

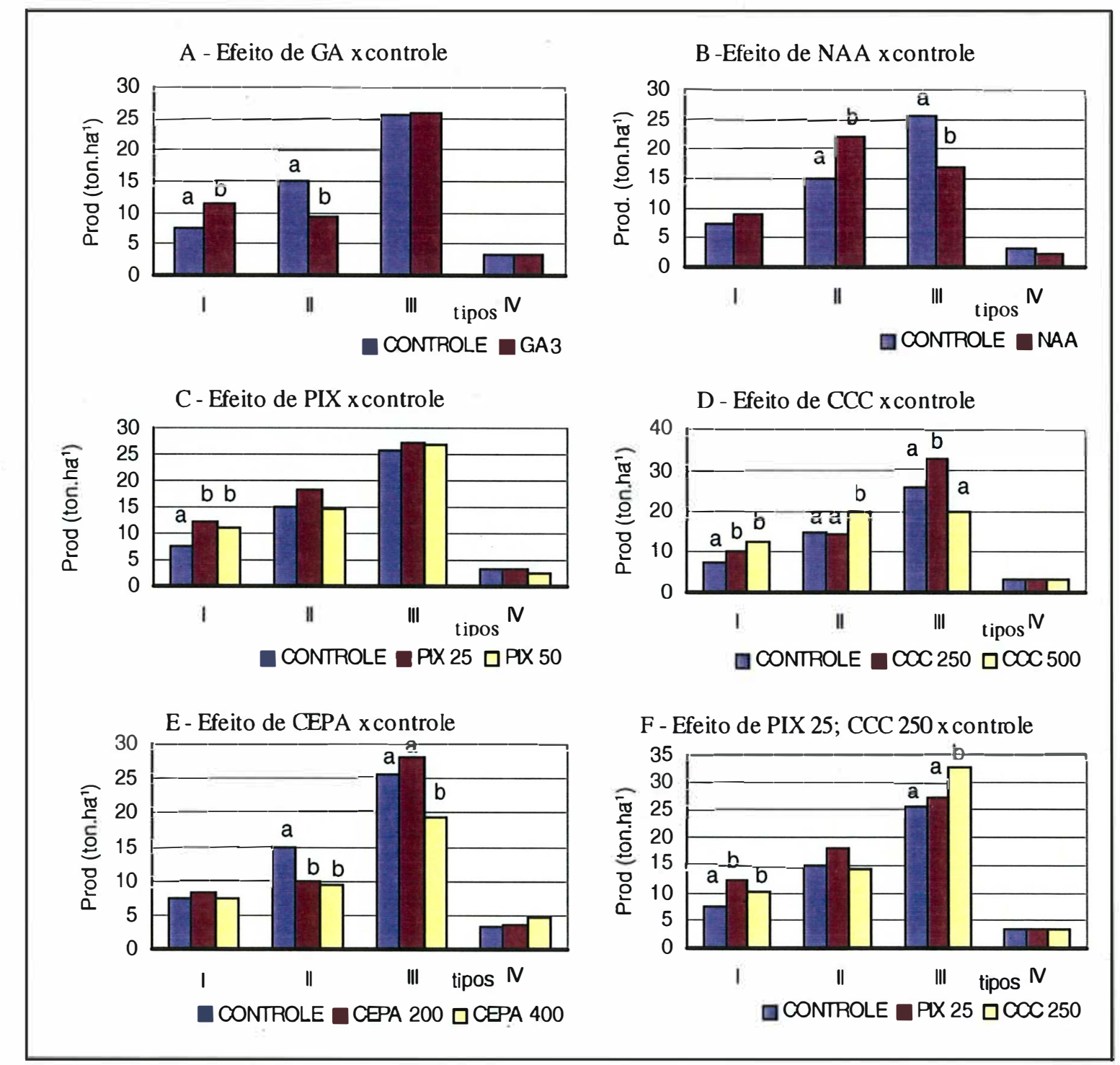

FIGURA 1 - Efeito de reguladores vegetais na produção e tipos de tubérculo-sementes da cultura de batata (Solanum tuberosum L., cv Achat). Letras distintas diferem entre si ao nível de 5\% de probabilidade.

Comparando os efeitos dos retardadores de crescimento (PIX 25 e CCC 250) com o controle, nota-se que a aplicação com CCC na menor concentração, mostrou maior produção de tubérculos do tipo III (F). 
Segundo Filgueira (1984), a homogeneidade no tamanho dos tubérculo-sementes é de grande importância, uma vez que sua comercialização feita em caixa de $30 \mathrm{~kg}$, pode conter número maior de sementes do tipo III, sem afetar o stand e a produção final.

Nickell (1994) mencionou que o efeito de retardadores de crescimento ocorre principalmente no meristema subapical, entretanto nas concentrações aplicadas no experimento, ocorreu efeito estimulatório em relação ao controle (TABELA 1 e 2), indicando ter ocorrido alterações enzimáticas, como mencionado por Sharma et al. (1998).

\subsection{CONCLUSÕES}

a) Os reguladores vegetais aplicados após a tuberização, promoveram alterações fisiológicas quanto à partição dos fotoassimilados.

b) A análise de carboidratos solúveis totais em folhas e tubérculos de batata, pode ser utilizada para detectar efeitos da aplicação de reguladores vegetais.

c) Nas condições de outono-inverno, os reguladores vegetais aplicados em baixas concentrações aumentaram a produção do tipo de tubérculo produzido, podendo ser utilizados de acordo com o objetivo da produção.

d) Os aumentos verificados em tubérculos do tipo I foram de: $53 \%$ para $\mathrm{GA}_{3}, 62 \%$ para PIX 25, 46\% para PIX 50, 37\% para CCC 250, 67\% para CCC 500. Para tubérculos do tipo II, o aumento foi de $33 \%$ para CCC 500 e $47 \%$ para NAA. CCC 250 , aumentou em $28 \%$ a produção de tubérculos do tipo III. 


\section{EFEITOS DE RETARDADORES DE CRESCIMENTO NO DESENVOLVIMENTO E PRODUTIVIDADE DA CULTURA DA BATATA (Solanum tuberosum L. cv Monalisa), APÓS TUBERIZAÇÃO ${ }^{1}$}

S. TAVARES ${ }^{2}$; A. A. LUCCHESI, Depto. de Ciências Biológicas - ESALQ/USP - CEP: 13418-900 - Piracicaba, SP.

\subsection{RESUMO}

O objetivo do presente trabalho, foi avaliar a influência de retardadores de crescimento, no desenvolvimento e produtividade da cultura da batata, cultivar Monalisa. Foram aplicados via foliar aos 45 dias após o plantio, cloreto de mepiquat (PIX) e cloreto de (2-cloroetil) trimetilamônio (CCC) nas concentrações de 25, 50 e 100 e 250, 500 e $1000 \mathrm{mg} \cdot \mathrm{L}^{-1}$, respectivamente, além do controle.

Os parâmetros analisados aos 14 e 28 dias após a aplicação foram: área foliar $\left(\mathrm{m}^{2}\right)$, massa de matéria seca de folhas $(\mathrm{g})$ e a relação entre massa de matéria seca $(\mathrm{g})$ e área foliar $\left(\mathrm{m}^{2}\right)$ e teor de clorofila $\left(\mathrm{g} \cdot \mathrm{m}^{-2}\right)$. Também foram determinados aos 28 dias após a aplicação, o teor de sólidos solúveis ( $\left({ }^{\circ}\right.$ Brix) em folhas e tubérculos de batata.

A colheita foi realizada aos 105 dias do plantio, a qual se verificou a produtividade, classificação quanto ao tipos de tubérculos-semente e a porcentagem de amido na massa de matéria seca.

\footnotetext{
${ }^{1}$ Parte da dissertação apresentada a ESALQ/USP em Fisiologia e Bioquímica de Plantas.

${ }^{2}$ Bolsista da CAPES, pós-graduando em Fisiologia e Bioquímica de Plantas - ESALQ/USP.
} 
Os resultados mostraram que os retardadores de crescimento aplicados no cultivar precoce Monalisa, não afetam a área foliar, massa de matéria seca das folhas, teor de clorofila, mas afetam o teor de açúcares em folhas e tubérculos de batata aos 28 DAA. Os retardadores de crescimento aplicados, estimulam a força de dreno dos tubérculos.

Os parâmetros (peso específico foliar, teor de sólidos solúveis, porcentagem de amido) utilizados, mostraram-se adequados para a interpretação dos resultados obtidos pela aplicação dos retardadores de crescimento, na cultura da batata.

Palavras chaves: Retardadores de crescimento, Solanum tuberosum, amido, produtividade

\section{EFFECTS OF GROWTH RETARDANTS ON GROWTH AND PRODUCTIVITY OF POTATO CROP (Solanum tuberosum L. cv Monalisa), AFTER TUBERIZATION.}

\subsection{SUMMARY}

The objective of the present research, was to evaluate the influence of growth retardants, on development and productivity of the potato crop, cultivar Monalisa. Were applied through foliar spraying, 45 days after planting, mepiquat chloride (PIX) and (2chloroethyl) trimethyl ammonium chloride (CCC), in the concentrations of 25, 50 and 100 and 250,500 and $1000 \mathrm{mg} . \mathrm{L}^{-1}$, respectively, besides the control.

The parameters analyzed 14 and 28 days after the application were: leaf area $\left(\mathrm{m}^{2}\right)$, dry matter mass of leaves $(\mathrm{g})$ and the relationship among dry matter mass $(\mathrm{g})$ and leaf area $\left(\mathrm{m}^{2}\right)$ and chlorophyll rate $\left(\mathrm{g} \cdot \mathrm{m}^{-2}\right)$. Were also determined soluble solids contents ( $\left.{ }^{\circ} \mathrm{Brix}\right)$ in leaves and tubers at 28 days after application.

The crop was harvest at 105 days of the planting, when the productivity, classification were verified to the seed tubers types and the percentage of starch in the dry matter weigth. 
The results showed that the application of growth retardants in early cultivar Monalisa, didn't affect the leaf area, dry matter weigth of the leaves and chlorophyll contents, but affected sugars content on leaf and tubers at 28 days after application. Growth retardants concentrations spraying can stimulate sink strenght tubers after tuberization. The parameters (specific leaf weight, soluble solids contents and starch rate), were effective to interprete results on growth retardants applied to potato crop.

Key words: Growth retardants, Solanum tuberosum, starch, productivity.

\subsection{INTRODUÇÃO}

O presente trabalho executado em condições de campo, teve por objetivo estudar a influência da aplicação de retardadores de crescimento no desenvolvimento e produtividade da cultura de batata, cultivar Monalisa. Resultados obtidos com o cultivar tardio Achat (ciclo longo de tuberização), demonstraram que retardadores de crescimento aplicados em baixas concentrações, podem atuar estimulando a produção de tubérculos sementes, sem afetar parâmetros como área foliar, massa de matéria seca de raízes, número de hastes e número de tubérculos por planta.

Vários trabalhos realizados, relatam resultados promissores com relação ao uso de retardadores vegetais na cultura da batata. Cruz (1982) conseguiu aumentar a produção de tubérculos, mesmo não tendo verificado alterações na área foliar, com aplicações de cloreto de mepiquat. Shadeque \& Pandita (1982) obtiveram aumento na produção de tubérculos de batata com a aplicação de chlormequat (CCC) na concentração de $500 \mathrm{mg} . \mathrm{L}^{-1}$, aos 50 dias após o plantio. Sekhon \& Singh (1985) aumentaram a produção de tubérculos-semente com a aplicação de CCC na dose de 600 ml.ha ${ }^{-1}$, cinco semanas após o plantio.

Guinazu et al. (1988) relacionaram o efeito de chlormequat com a inibição da síntese de giberelinas livres. Zakaryan \& Virabyan (1976) verificaram inibição de síntese de clorofilas, durante o período inicial de desenvolvimento e atraso na degradação de 
clorofilas durante o período final de desenvolvimento das plantas tratadas com chlormequat. O CCC tem ação de retardador de crescimento por inibir a passagem de geranilgeranil pirofosfato para copalil pirofosfato, na biossíntese de giberelinas. Porra \& Meisch (1984) relataram que a biossíntese de clorofila se dá pela ligação de geranilgeranil pirofosfato à clorofilina a. Portanto, a inibição da síntese de giberelinas, poderia disponibilizar geranilgeranil pirofosfato para a biossíntese de clorofilas.

Sharma et al. (1998) estudando a atividade das enzimas sacarose sintetase e sacarose fosfato sintetase, detectaram aumento de $10 \%$ no teor de amido nos tubérculos de plantas tratadas com chlormequat. Também foi encontrado alto teor de carboidratos solúveis na parte aérea das plantas, indicando reflexo de atividade fotossintética devido ao alto teor de clorofilas nas folhas (Sharma, 1997). Segundo o mesmo autor, o aumento na produção de tubérculos em plantas tratadas com chlormequat (CCC), estaria relacionado com o aumento da eficiência desses tubérculos em converter sacarose em amido.

\subsection{MATERIAL E MÉTODOS}

O presente trabalho foi instalado no sítio Roseira, (Latossolo vermelho amarelo, fase arenosa), localizado no município de Sumaré, Estado de São Paulo. Foram utilizados tubérculos-sementes tipo II do cultivar Monalisa, semeados no final do outono, no espaçamento de 0,80 m entre linhas e 0,30 m entre plantas. Foram aplicados via foliar chlormequat [cloreto (2-cloroetil) trimetilamônio (CCC)] nas concentrações de 250, 500 e $1000 \mathrm{mg} . \mathrm{L}^{-1}$, cloreto de mepiquat (PIX) 25, 50 e $100 \mathrm{mg} . \mathrm{L}^{-1}$, além do controle.

O delineamento experimental adotado foi blocos casualizados, com quatro repetições e com 65 plantas por parcela. Aplicou-se o teste Tukey, para a comparação de médias ao nível de $5 \%$ de probabilidade para a diferença mínima significativa.

Os parâmetros analisados foram: área foliar $\left(\mathrm{m}^{2}\right)$, massa de matéria seca $(\mathrm{g}) \mathrm{e}$ matéria seca produzida por unidade de área foliar [peso específico foliar $\left(\mathrm{g} \cdot \mathrm{m}^{-2}\right)$ ], aos 14 e 28 dias após a aplicação (DAA). O teor de clorofila $\left(\mathrm{g} \cdot \mathrm{m}^{-2}\right.$ ) foi obtido através do uso do 
medidor de clorofila (SPAD-502) em folhas previamente marcadas. Após 28 dias da aplicação, determinou-se o teor de sólidos solúveis ( ${ }^{\circ}$ Brix) em folhas e tubérculos com refratômetro de mesa. A área foliar foi obtida destacando-se todas as folhas da planta de batata, submetendo-as diretamente ao integrador de área (AREA METER-3100) e a massa de matéria seca (g), por desidratação até massa constante, em estufas com temperatura de $65^{\circ} \mathrm{C}$ e ventilação forçada. O peso específico foliar foi obtido pela razão entre massa de matéria seca das folhas e sua área foliar.

A colheita dos tubérculos (média de 10 plantas por parcela), foi realizada aos 105 dias após o plantio e a classificação quanto ao tipo de tubérculos-sementes produzidos, de acordo com as Normas Gerais para Certificação de batata-semente (Brasil, 1988).

Para a determinação da porcentagem de amido, baseado no teor de matéria seca dos tubérculos, utilizou-se do método enzimático (Rickard \& Behn, 1987), adaptado por Somogy e Nelson (1944), através de espectrofotometria (absorbância em 535 nm).

\subsection{RESULTADOS E DISCUSSÃO}

Pela TABELA 1, os dados obtidos revelam que não houve efeito dos retardadores de crescimento na área foliar e massa de matéria seca das plantas tratadas, comparadas com o controle, 14 e 28 dias após a aplicação. Cruz (1982) mesmo não obtendo variação significativa na área foliar, conseguiu-se aumento de 19,1\% na produção de tubérculos com aplicações foliares de cloreto de mepiquat no cultivar Omega. Houve redução significativa na massa de matéria seca, com cloreto de mepiquat (100 mg. $\left.\mathrm{L}^{-1}\right)$ e aumento com chlormequat $\left(250 \mathrm{mg} . \mathrm{L}^{-1}\right)$, aos 28 dias após a aplicação.

Notou-se aos 14 dias após a aplicação, que PIX 25, CCC 250 e CCC 500, reduziram a matéria seca foliar produzida $(\mathrm{g})$ por unidade de área foliar $\left(\mathrm{m}^{2}\right)$ e PIX 50 apresentou índice próximo do controle. Houve um acúmulo de matéria seca produzida na parte aérea com as maiores concentrações aplicadas. 
TABELA 1 - Influência de retardadores de crescimento na área foliar ( $\left.\mathrm{AF} \mathrm{em} \mathrm{m}^{2}\right)$, massa de matéria seca (MMS em gramas) e peso específico foliar (MMS/AF), na cultura da batata (Solanum tuberosum L. cv Monalisa), aos 14 e 28 dias após a aplicação. Valores de F, Tukey (5\%) e coeficiente de variação.

\begin{tabular}{lcccccc}
\hline & $\begin{array}{c}\text { Área foliar } \\
\left(\mathrm{m}^{2}\right)\end{array}$ & \multicolumn{2}{c}{$\begin{array}{c}\text { Massa de matéria seca } \\
(\mathrm{g})\end{array}$} & $\begin{array}{c}\text { Peso específico foliar } \\
\text { MMS/AF }-\left(\mathrm{g} . \mathrm{m}^{-2}\right)\end{array}$ \\
\hline tratamentos & 14 & 28 & 14 & 28 & 14 & 28 \\
CONTROLE & 0,595 & 0,579 & 19,18 & $15,66 \mathrm{ab}$ & 28,8 & 30,1 \\
PIX 25 & 0,665 & 0,609 & 19,20 & $18,38 \mathrm{ab}$ & 27,8 & 29,0 \\
PIX 50 & 0,721 & 0,537 & 14,40 & $15,49 \mathrm{ab}$ & 29,5 & 28,5 \\
PIX 100 & 0,517 & 0,533 & 14,59 & $10,68 \mathrm{~b}$ & 32,0 & 30,3 \\
CCC 250 & 0,613 & 0,583 & 16,19 & $22,42 \mathrm{a}$ & 23,5 & 25,5 \\
CCC 500 & 0,493 & 0,374 & 16,96 & $13,73 \mathrm{ab}$ & 24,9 & 29,2 \\
CCC 1000 & 0,504 & 0,739 & 15,31 & $17,10 \mathrm{ab}$ & 32,1 & 27,0 \\
\hline F (trat) & $2,46 \mathrm{n} \mathrm{s}$ & $1,56 \mathrm{n} \mathrm{s}$ & $1,97 \mathrm{n} \mathrm{s}$ & $2,61 *$ & - & - \\
CV (\%) & 18,86 & 30,74 & 17,25 & 4,86 & - & - \\
\hline
\end{tabular}

${ }^{\text {ns }}$ não significativo

" significativo ao nível de $5 \%$ de probabilidade

Isso pode indicar a ação dos retardadores de crescimento na velocidade de exportação dos assimilados pela ação da enzima sacarose fosfato sintetase (Sharma et al., 1998) ou à maior atividade fotossintética devido ao atraso na degradação de clorofilas (Zakaryan \& Virabyan, 1976). Aos 28 dias após a aplicação, o efeito na redução da matéria seca produzida por unidade de área foliar foi observada com PIX $\left(25 \mathrm{mg} . \mathrm{L}^{-1}\right.$ e 50 $\left.\mathrm{mg} \cdot \mathrm{L}^{-1}\right)$ e chlormequat em todas as concentrações aplicadas, sugerindo maior período de ação na planta tratada. A maior concentração de PIX, apresentou peso específico foliar próximo ao controle. Pela análise de variância, não houve variação da média entre repetições. 
Pela TABELA 2, não se verificou variação no teor de clorofila, em todas as avaliações realizadas. Entretanto, notou-se tendência de atraso na degradação de clorofilas, para todos os tratamentos aos 28 dias após a aplicação. $\mathrm{O}$ atraso na degradação de clorofilas no período final de desenvolvimento de plantas tratadas com chlormequat, foi observado por Zakaryan \& Virabyan (1976).

TABELA 2 - Influência de retardadores de crescimento no teor de clorofila (g. $\left.\mathrm{m}^{2}\right)$, sólidos solúveis ( ${ }^{\circ}$ Brix) em folhas e tubérculos e porcentagem de amido em tubérculos na cultura de batata (Solanum tuberosum L. cv Monalisa). Valores de F, Tukey (5\%) e coeficiente de variação.

\begin{tabular}{|c|c|c|c|c|c|c|}
\hline \multirow[b]{2}{*}{ tratamentos } & \multicolumn{3}{|c|}{$\begin{array}{l}\text { Teor de clorofila } \\
\qquad\left(\mathrm{g} . \mathrm{m}^{2}\right)\end{array}$} & \multicolumn{2}{|c|}{$\begin{array}{l}\text { Sólidos solúveis } \\
\text { ( }{ }^{\circ} \text { Brix) - } 28 \text { daa }\end{array}$} & \multirow{2}{*}{$\begin{array}{c}\text { amido } \\
\% \\
\text { tubérculos }\end{array}$} \\
\hline & inicial & 14 (daa) & 28 (daa) & folhas & tubérculos & \\
\hline CONTROLE & 3,83 & 3,43 & 2,80 & $8,65 a b$ & $10,70 \mathrm{~b}$ & 78,86 \\
\hline PIX 25 & 3,99 & 3,41 & 2,84 & $6,80 \mathrm{~b}$ & $13,45 \mathrm{a}$ & 82,29 \\
\hline PIX 50 & 4,06 & 3,82 & 3,44 & $8,72 \mathrm{ab}$ & $12,57 \mathrm{a}$ & 80,89 \\
\hline PIX 100 & 3,84 & 3,18 & 3,09 & $7,87 \mathrm{ab}$ & $12,95 \mathrm{a}$ & 77,45 \\
\hline CCC 250 & 4,12 & 3,61 & 3,28 & $9,65 \mathrm{a}$ & $12,77 \mathrm{a}$ & 81,40 \\
\hline CCC 500 & 3,86 & 3,48 & 2,98 & $7,30 \mathrm{ab}$ & $13,35 \mathrm{a}$ & 79,45 \\
\hline CCC 1000 & 4,07 & 3,80 & 2,85 & $8,85 \mathrm{ab}$ & $12,55 \mathrm{a}$ & 79,77 \\
\hline F (trat) & $0,58 \mathrm{n} \mathrm{s}$ & $0,86 \mathrm{n} \mathrm{s}$ & $0,78 \mathrm{n} \mathrm{s}$ & $3,72 *$ & $9,79 *$ & $0,67 \mathrm{n} \mathrm{s}$ \\
\hline CV (\%) & 6,89 & 11,94 & 15,61 & 12,38 & 4,64 & 4,63 \\
\hline
\end{tabular}

${ }^{\text {ñs }}$ não significativo

" significativo ao nível de $5 \%$ de probabilidade

O teor de sólidos solúveis ( ${ }^{\circ}$ Brix) encontrado nas folhas não apresentaram diferenças significativas em relação ao controle, porém ocorreu variação significativa entre as menores concentrações de cloreto de mepiquat e chlormequat aplicadas (14 DAA). Todos os retardadores de crescimento, aumentaram o teor de sólidos solúveis 
( ${ }^{\circ}$ Brix) nos tubérculos de plantas de batata tratadas, indicando eficiência na força de dreno dos tubérculos.

Apesar de não ter ocorrido variação significativa na porcentagem de amido nos tubérculos de batata, nota-se acréscimo de 4,2 e 5,4\% para as menores concentrações de chlormequat e cloreto de mepiquat, respectivamente. Segundo Sharma et al. (1998), o aumento de $10 \%$ no teor de amido, verificado em plantas tratadas com chlormequat, estaria relacionado com o aumento da eficiência de conversão de sacarose em amido pelos tubérculos.

TABELA 3 - Influência de retardadores de crescimento na produtividade e na classificação de tipos de tubérculos-semente (ton. ha $^{-1}$ ) na cultura da batata (Solanum tuberosum L. cv Monalisa). Valores de F, Tukey ( $5 \%$ ) e coeficiente de variação.

\begin{tabular}{lcccccc}
\hline & $\begin{array}{c}\text { Produtividade } \\
\left(\text { ton.h }{ }^{-1}\right)\end{array}$ & \multicolumn{4}{c}{$\begin{array}{c}\text { Tipos de tubérculos-sementes } \\
(\text { ton.ha }\end{array}$} \\
& total & comercial & I & II & III & IV \\
\hline tratamentos & $45,12 \mathrm{ab}$ & $37,41 \mathrm{a}$ & $10,83 \mathrm{ab}$ & $15,63 \mathrm{ab}$ & 12,18 & 3,49 \\
\hline CONTROLE & $43,55 \mathrm{ab}$ & $40,14 \mathrm{a}$ & $10,89 \mathrm{ab}$ & $17,77 \mathrm{a}$ & 11,48 & 3,21 \\
PIX 25 & $34,81 \mathrm{~d}$ & $30,98 \mathrm{~b}$ & $10,12 \mathrm{ab}$ & $9,56 \mathrm{c}$ & 11,29 & 3,82 \\
PIX 50 & $34,91 \mathrm{~cd}$ & $30,18 \mathrm{~b}$ & $7,65 \mathrm{~b}$ & $14,01 \mathrm{abc}$ & 8,50 & 4,74 \\
PIX 100 & $40,50 \mathrm{bc}$ & $37,52 \mathrm{a}$ & $11,61 \mathrm{ab}$ & $13,78 \mathrm{abc}$ & 12,11 & 2,98 \\
CCC 250 & $47,35 \mathrm{a}$ & $42,45 \mathrm{a}$ & $12,57 \mathrm{a}$ & $17,71 \mathrm{a}$ & 12,14 & 4,90 \\
CCC 500 & $35,93 \mathrm{~cd}$ & $31,66 \mathrm{~b}$ & $7,85 \mathrm{~b}$ & $10,96 \mathrm{bc}$ & 12,85 & 4,26 \\
CCC 1000 & $15,97 *$ & $15,97 *$ & $3,61 *$ & $7,83 *$ & $1,05 \mathrm{n} \mathrm{s}$ & $0,68 \mathrm{n} \mathrm{s}$ \\
\hline F (trat) & 6,07 & 6,77 & 19,05 & 15,82 & 24,04 & 46,92 \\
CV $(\%)$ & & & & & & \\
\hline
\end{tabular}

${ }^{\text {ns }}$ não significativo

* significativo ao nível de $5 \%$ de probabilidade

Os dados de produção (ton.ha ${ }^{-1}$ ) relacionados na TABELA 3, indicam que a aplicação dos retardadores de crescimento nas maiores concentrações, diminuíram a produção de tubérculos de batata. Chlormequat na concentração de $500 \mathrm{mg} . \mathrm{L}^{-1}$, 
aumentou $4,9 \%$ a produção total e $13,47 \%$ a produção comercial de tubérculos. Resultados semelhantes foram obtidos com o uso de chlormequat ( Sekhon \& Singh, 1985; Shadeque \& Pandita, 1982). A classificação quanto ao tipo de tubérculos-semente, indicou que somente o cloreto de mepiquat $\left(50 \mathrm{mg} \cdot \mathrm{L}^{-1}\right)$, afetou significativamente a produção de tubérculos do tipo II, em relação ao controle.

\subsection{CONCLUSÕES}

a) Os retardadores de crescimento aplicados após a tuberização, não afetam a área foliar, massa de matéria seca foliar e teor de clorofila, mas afetam o teor de açúcares em folhas e tubérculos de batata, aos 28 dias após a aplicação.

b) As menores concentrações de retardadores de crescimento aplicadas após a tuberização, estimulam a força de dreno dos tubérculos de batata.

c) Os parâmetros (peso específico foliar, teor de sólidos solúveis e porcentagem de amido) utilizados, mostraram-se eficientes na interpretação dos resultados obtidos com a aplicação de retardadores de crescimento na cultura da batata.

d) Concentrações elevadas dos retardadores de crescimento utilizados, podem inibir a produção de tubérculos-sementes dos tipos I e II. 


\section{CONCLUSÕES GERAIS}

a) As diferenças obtidas na produção de tubérculos sementes, verificados nos cultivares Achat e Monalisa, confirmam a ação fisiológica dos reguladores vegetais.

b) Após a tuberização, quando ocorre a máxima expansão foliar, os reguladores vegetais nas doses aplicadas, não afetam a área foliar, comprimento dos estolões, número de hastes e de tubérculos por planta, mas afetam o teor de açúcares em folhas e tubérculos de batata.

c) Os parâmetros que melhor expressaram o desempenho dos reguladores estudados foram: peso específico foliar, teor de carboidratos em folhas e tubérculos, taxa de crescimento relativo (TCR), taxa de produção de matéria seca (TPMS) e taxa assimilatória líquida (TAL).

d) Nas condições de outono-inverno, os reguladores vegetais em baixas concentrações podem estimular a produção final de tubérculos.

e) Os reguladores vegetais aplicados, aumentaram a produção de tubérculos do tipo I em: $53 \%$ com GA 3 (15 mg. $\left.\mathrm{L}^{-1}\right) ; 62 \%$ com PIX (25 mg.L $\left.\mathrm{L}^{-1}\right) ; 46 \%$ com PIX (50mg.L $\mathrm{L}^{-1}$ ); 37\% com CCC (250 mg. $\left.\mathrm{L}^{-1}\right)$ e $67 \%$ com CCC (500 mg. $\left.\mathrm{L}^{-1}\right)$.

f) A produção de tubérculos do tipo II, foi aumentada em $47 \%$ com NAA 15 mg. $\mathrm{L}^{-1}$ e $33 \%$ com CCC $500 \mathrm{mg} . \mathrm{L}^{-1}$. 
g) CCC na concentração de $250 \mathrm{mg} \cdot \mathrm{L}^{-1}$, também aumentou a produção de tubérculos do tipo III em $28 \%$.

h) O cultivar Achat (ciclo longo de tuberização), apresentou maiores alterações no tipo de tubérculos sementes, quando comparado ao cultivar Monalisa (ciclo curto), sob a influência dos retardadores de crescimento. 


\section{REFERÊNCIAS BIBLIOGRÁFICAS}

AHMED, C.M.S.; TAHIR, M. Effect of growth regulators on the number and volume of tubers in potato (Solanum tuberosum L.). Sarhad Journal of Agriculture, v.11, n. 5, p. 575-580, 1995.

ALVIM, R.; ALVIM, P.T. Efeito da densidade de plantio no aproveitamento da energia luminosa pelo milho (Zea mays) e pelo feijão (Phaseolus vulgaris) em outras culturas exclusivas e consorciadas. Turrialba, v. 19, p. 389-393, 1969.

ANUÁRIO ESTATÍSTICO DO BRASIL - 1996, v. 56, p. 3-43.

ASSOCIATION OF OFFICIAL ANALYTICAL CHEMISTS. Official methods of analysis of the Association of Official Analytical Chemistry. 12. Ed. Washington, 1975. $1094 \mathrm{p}$.

BALAMANI, V; POOVAIAH, B.W. Retardation of shoot growth and promotion of tuber growth of potato plants by paclobutrazol. American Potato Journal, v. 62, n. 7, p. 363-369, 1985. 
BLACKMAN, G.E. ; WILSON, G.L. Physiological studies in the analysis of differential effects of light intensity on the net assimilation rate, leaf area ratio and relative growth rate of different species. Annals of Botany, v. 59, n. 15, p. 373-408, 1951.

BLACKMAN, G.E. The application of the concepts of growth to the assessement of productivity. In: UNESCO. Functioning of terrestrial ecosystems at the primary production level. Paris, 1968, p. 243-259.

BODLAENDER, K.B.A.; VAN DE WAART, M. Influence of gibberellic acid (GA3) applied to the crop on growth, yield and tuber size distribution of seed potatoes. Netherlands Journal of Agricultural Science, v. 37, n. 3, p. 185-196, 1989.

BRASIL. Ministério da Agricultura. Normas gerais para certificação de batatasemente. Brasília: SNAP, 1988, 30p.

BRASIL. Resolução n. 12/78 de 24 de julho de 1978 da Comissão Nacional de Normas e Padrões para Alimentos. Diário Oficial, Brasília, 24 de julho de 1978, seção 1, pt. I. Aprova as normas técnicas especiais do Estado de São Paulo, revistas pela CNNPA, relativas a alimentos (e bebidas).

BUTTERY, B.R.; BUZZELL, R.I. Some differences between soybean cultivars observed by growth analysis. Canadian Journal of Plant Science, v. 52, n. 1, p. 13$20,1972$.

CASTRO, P.R.C.; MELOTTO, E.; HARADA, E. Efeitos de giberelinas na emergência e no desenvolvimento de batata inglesa. Ecossistema, v. 21, p. 5-10, 1996. 
CRUZ, L.S.P. Emprego de cloreto de mepiquat em cultura de batata (Solanum tuberosum L.). In: CONGRESSO BRASILEIRO DE HERBICIDAS E ERVAS DANINHAS, 14.; CONGRESSO DE LA ASOCIATION LATINOAMERICANA DE MALEZAS, 6., Campinas, 1982. Resumos. Campinas: SBHED, 1982. p. 162163.

DUBOIS, M.; GILLES, K.A.; HAMILTONS, J.K.; REBERS, P.A.; SMITH, F. Colorimetric method for determination of sugars and related substances. Analytical Chemistry, v. 28 , p. $350-356,1956$.

DYSON, P.W.; HUMPHRIES, E.C. Modification of growth habit of majestic potato by growth regulators applied ed at different times. Annals of Applied Biology, v.58, p. 171-182, 1966.

FELIPPE, G.M. Desenvolvimento. In: FERRI, M.G. (Coord.) Fisiologia vegetal. EDUSP, São Paulo: 1979a. v. 2, p. 1-37.

FELIPPE, G.M. Etileno. In: FERRI, M.G. (Coord.) Fisiologia vegetal. EDUSP, São Paulo: 1979b. v. 2, p. 163-192.

FILGUEIRA, F.A.R. Circular Técnica. EMGOPA, n. 6, p. 5-18, 1984.

GOLOVKO, T.K.; TABALENKOVA, G.N. Effect of chlorocholine chloride on starch synthesizing ability and yield of potato tubers. Fiziologiya Rastenii, v. 36, n. 3, p. $544-550,1989$.

GOWDA, I.N.D.; KRISHNAPPA, K.S. Effect of pre-harvest foliar spray of maleic hydrazide on growth, yield and quality of potato. Madras Agricultural Journal, v. 71, n. 3, p. $182-188,1984$ 
GUINAZU, M.; ABDALA, G.; TIZIO, R. Effect of free and conjugated gibberellins on roots of potato cuttings treated with CCC [(2-chloroethyl) trimethylammonium chloride] in relation to tuber formation. Journal of Plant Physiology, v. 132, n. 6, p. $725-730,1988$.

HOPKINS, W.G. The role of hormones in plant development. In: Introduction to plant physiology, John Wiley \& Sons, 1995, p. 285-295.

ISLAM, M.T.; ALAM, S.M.M. Effect of some growth regulators on growth, yield and chemical composition of potato. Bangladesh Journal of Training and Development, v. 2, n. 2, p. 33-39, 1989.

JUZL, M. The effect of leaf area index on the yield of very early potato cultivars Prior and Impala. Acta Universitatis Agriculturae Facultas Agronomica, v. 42, n. 1/2, p. 127-136, 1994.

KHAN, J.; SHAH, J.; KHAN, T. Effect of seed and foliar application of plant growth regulator on the growth and yield of potato. Sarhad Journal of Agriculture, v. 11, n. 5, p. $581-583,1995$.

KOLLER, D.C.; HILLER, L.K. Response of Russet Burbank potatoes to ethephon sprays. American Potato Journal, v. 65, n. 9, p. 529-534, 1988.

LANGILLE, A.R.; HEPLER, P.R. Effect of three anti-gibberellin growth retardants on tuberization of induced and non induced Katahdin potato leaf-bud cuttings. American Potato Journal, v. 69, n. 2, p. 131-141, 1992.

LI , P.H. (Ed.) Potato physiology. Orlando: Academic Press, 1985, 586p. 
LUCCHESI, A. A.; MINAMI, K. Análise quantitativa de crescimento vegetal em cultivares de morangueiro (Fragaria spp.), sob a influência de fito-reguladores de crescimento. Anais da Escola Superior de Agricultura "Luiz de Queiroz", v. 37, p. 555-593, 1980.

MAGALHÃES, A.C.N. Análise quantitativa do crescimento. In: FERRI, M.G. (Coord.) Fisiologia vegetal. EDUSP, São Paulo: 1979, v. 1, p. 331-350.

MARCHNER, H.; SATTELMARCHER, B.; BANGERTH, F. Growth rate of potato tubers and endogenous contents of indolylacetic acid and abscisic acid. Physiologia Plantarum, v. 60, n. 1, p. 16-20, 1984.

MATTAR, I.A.; ABDUL, K.S. Effect of some concentrations of gibberellic acid and cycocel and of application date on the growth and yield of spring potatoes at Khabat/Erbil. Iraqi Journal of Agricultural Sciences, v. 6, n. 3, p. 15-32, 1988.

MAUROMICALE, G. Research on the application of various regulators to the potato in the autumn-spring cycle. Rivista di Ortoflorofrutticoltura, v. 66, n. 1, p. 75-84, 1982.

MELTZER, $H$. The effect of 2-chloroethylphosphonic acid on the tuber number and yield of potato cultivars of different maturity classes. Potato Research, v. 27, n. 3, p. 271-284, 1984.

MELTZER, $H$. The effect of growth regulators on the relationship between numbers of stems and tubers in potato. Potato Research, v. 35, n. 3, p. 297-303, 1992. 
NELSON, N.A. Photometric adaptation of the Somogy method fo the determination of glucose. Journal of Biological Chemistry, v. 153, p. 375-380, 1944.

NICKELL, L.G. Plant growth regulators in agriculture and horticulture. In: HEDIN, P.A. (Ed.) Bioregulators for crop protection and pest control. Washington: American Chemical Society, 1994. P. 1-13. (ACS. Symposium Series, 557).

NICKELL, L.G. Plant growth regulating chemicals. CRC, Boca Raton: Press, 1988, v. $2,256 \mathrm{p}$.

PAULA, M.B. Produção de matéria seca e absorção de macronutrientes por cultivares de batata. Horticultura Brasileira, v. 4, n. 1, p. 10-16, 1986.

PIETERSE, B.J.; HAMMES, P.S.; NEL, P.C. Manipulation of potato tuber size with growth retardants. Crop Production, v. 11, p. 95-96, 99-100, 1982.

PORRA, R. J.; ULRICH MEISCH, H. The biosynthesis of chlorophyll. Trends in Biochemical Sciences, v. 9, p. 99-104, 1984.

RADFORD, P. J. Growth analysis formulae: their use and abuse. Crop Science, v. 7, p. 171-175, 1967.

REDDY, J.R.S.; KRISNAPPA, K.S.; NAGARAJAIAH, C. Effect of Fito-Hormon on the yield attributes and yield of potato. Mysore Journal of Agricultural Sciences, v. 25, n. 3 , p. $350-354,1991$.

REX, B.L. Effect of two plant growth regulators on the yield and quality of Russet Burbank potatoes. Potato Research, v. 35, n. 3, p. 227-233, 1992. 
RICKARD, J.; BEHN, K.R. Evaluation of acid and enzyme hydrolytic methods for the determination of cassava starch. Journal of Science Food and Agriculture, v. 41, n. 4 , p. $373-379,1987$

SACHS, R.M. Stem elongation. Annual Review of Plant Physiology, v. 16, p. 73-96, 1965.

SEKHON, H.S.; SINGH, M. Effect of growth regulators and nitrogen on the growth, number and size of seed tubers and yield of potatoes. Journal of Agricultural Science, v. 104, n. 1, p. 99-106, 1985.

SHADEQUE, A.; PANDITA, M.L. Effect of cycocel (CCC) as foliar spray on growth, yield and quality of potato (Solanum tuberosum L.). Journal of Research Assam Agricultural University, v. 3, n. 1, p. 34-39, 1982.

SHARMA, N.; KAUR, N.; GUPTA, A.K. Effect of chlorocholine chloride sprays on the carbohydrate composition and activities of sucrose metabolising enzymes im potato. Plant Growth Regulation, v. 26, p. 97-103, 1998.

SOARES, M.H.G.; RAMOS, R.M.; SIMM, C.R. Efeito da aplicação do cloreto de mepiquat na cultura de batata (Solanum tuberosum L.). In: CONGRESSO BRASILEIRO DE HERBICIDAS E ERVAS DANINHAS, 14,; CONGRESSO DE LA ASOCIATION LATINOAMERICANA DE MALEZAS, 6., Campinas, 1982. Resumos. Campinas: SBHED, 1982. p.161-162.

SOMOGY, M. Determination of blood sugar. Journal of Biological Chemistry, v. 160, p. $69-73,1945$ 
SCHAUPMEYER, C.; FETH, G.; CURRY, D.; SMYRL, T.; DENCH, M.; HUNG, J. Effects of Alar (daminozide) on tuber set and tuber size of four potato cultivars. In: ALBERTA HORTICULTURAL RESEARCH CENTER. Annual Report - 1985. Resumo on the CAB Abstracts on CD-ROM, p. 33-34, 1985.

VALIO, I.F.M. Auxinas. In: FERRI, M.G. (Coord.) Fisiologia vegetal. EDUSP, São Paulo: 1979 , v. 2, p. 39-72.

WATSON, D. J. The physiological basis of variation in yield. Advances in Agronomy, v. 4, p. 101-145, 1952.

YADA, R.Y.; COFFIN, R.H.; KEENAN, M.K.; FITTS, M.; DUFAULT, C.; TAI, G.C.C. The effect of maleic hydrazide (potassium salt) on potato yield, sugar content and chip color of Kennebec and Norchip cultivars. American Potato Journal, v. 68, n. 10, p. 705-709, 1991.

ZAKARYAN, N.; VIRABYAN, A. Effect of CCC on chlorophyll metabolism in potato leaves. Uchenye Zapiski Erevanskogo Universiteta, n. 132, p. 102-110, 1976. Resumo em CAB Abstracts on CD-ROM, 1976. 